3-15-2011

\title{
Climatic Controls on the Snowmelt Hydrology of the Northern Rocky Mountains
}

Gregory T. Pederson

Northern Rocky Mountain Science Center

Stephen T. Gray

University of Arizona

Toby Ault

University of Arizona

Wendy Marsh

Northern Rocky Mountain Science Center

Daniel B. Fagre

Northern Rocky Mountain Science Center

See next page for additional authors

Follow this and additional works at: https://cedar.wwu.edu/esci_facpubs

Part of the Environmental Sciences Commons

\section{Recommended Citation}

Pederson, Gregory T.; Gray, Stephen T.; Ault, Toby; Marsh, Wendy; Fagre, Daniel B.; Bunn, Andrew Godard; Woodhouse, Connie A.; and Graumlich, Lisa, "Climatic Controls on the Snowmelt Hydrology of the Northern Rocky Mountains" (2011). Environmental Sciences Faculty and Staff Publications. 7.

https://cedar.wwu.edu/esci_facpubs/7 
Authors

Gregory T. Pederson, Stephen T. Gray, Toby Ault, Wendy Marsh, Daniel B. Fagre, Andrew Godard Bunn, Connie A. Woodhouse, and Lisa Graumlich 


\title{
Climatic Controls on the Snowmelt Hydrology of the Northern Rocky Mountains
}

\author{
Gregory T. Pederson, ${ }^{*+}$ Stephen T. Gray,\# Toby Ault, ${ }^{@}$ Wendy Marsh, \& Daniel B. FAgre, \\ ANDrew G. BunN, ${ }^{* *}$ CONNIE A. WOOdHOUSE, ${ }^{++}$AND LisA J. GraumLICH ${ }^{\# \#}$ \\ * U.S. Geological Survey, Northern Rocky Mountain Science Center, Bozeman, Montana \\ ${ }^{+}$School of Natural Resources, The University of Arizona, Tucson, Arizona

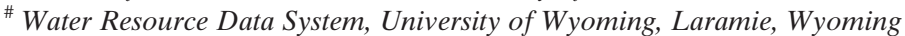 \\ ${ }^{\circledR}$ Geosciences Department, The University of Arizona, Tucson, Arizona \\ \& Big Sky Institute, Montana State University, Bozeman, Montana \\ ** Huxley College, Western Washington University, Bellingham, Washington \\ ${ }^{++}$School of Geography and Development, The University of Arizona, Tucson, Arizona \\ \#\# College of the Environment, University of Washington, Seattle, Washington
}

(Manuscript received 15 March 2010, in final form 15 November 2010)

\begin{abstract}
The northern Rocky Mountains (NRMs) are a critical headwaters region with the majority of water resources originating from mountain snowpack. Observations showing declines in western U.S. snowpack have implications for water resources and biophysical processes in high-mountain environments. This study investigates oceanic and atmospheric controls underlying changes in timing, variability, and trends documented across the entire hydroclimatic-monitoring system within critical NRM watersheds. Analyses were conducted using records from 25 snow telemetry (SNOTEL) stations, 1481 April snow course records, stream gauge records from 14 relatively unimpaired rivers, and 37 valley meteorological stations. Over the past four decades, midelevation SNOTEL records show a tendency toward decreased snowpack with peak snow water equivalent (SWE) arriving and melting out earlier. Temperature records show significant seasonal and annual decreases in the number of frost days $\left(\right.$ days $\leq 0^{\circ} \mathrm{C}$ ) and changes in spring minimum temperatures that correspond with atmospheric circulation changes and surface-albedo feedbacks in March and April. Warmer spring temperatures coupled with increases in mean and variance of spring precipitation correspond strongly to earlier snowmeltout, an increased number of snow-free days, and observed changes in streamflow timing and discharge. The majority of the variability in peak and total annual snowpack and streamflow, however, is explained by season-dependent interannual-to-interdecadal changes in atmospheric circulation associated with Pacific Ocean sea surface temperatures. Over recent decades, increased spring precipitation appears to be buffering NRM total annual streamflow from what would otherwise be greater snow-related declines in hydrologic yield. Results have important implications for ecosystems, water resources, and long-leadforecasting capabilities.
\end{abstract}

\section{Introduction}

Much of the western United States and Canada is characterized by an arid to semiarid climate, and the majority (up to $80 \%$ or more) of surface water in this region originates as mountain snowpack (Hamlet et al. 2007; Serreze et al. 1999; Stewart et al. 2005). Snow serves as a natural reservoir for water that is released over the spring [April-June (AMJ)], summer [July-September

Corresponding author address: Gregory T. Pederson, U.S. Geological Survey, Northern Rocky Mountain Science Center, 2327 University Way (Box 2), Bozeman, MT 59715.

E-mail: gpederson@usgs.gov
(JAS)], and fall [October-December (OND)], thereby providing municipal and industrial water supplies to support a rapidly growing population, as well as furnishing water for energy production, agriculture, and ecosystems. In turn, both the quantity and timing of water released from snowpack are critical societal and environmental concerns. A growing number of studies have demonstrated that, since 1950, western North America has experienced a substantial decline in peak snow water equivalent (SWE; Das et al. 2009; Mote et al. 2005; Pierce et al. 2008) and subsequently a reduced and earlier snowmelt runoff (Aguado et al. 1992; Cayan et al. 2001; Dettinger and Cayan 1995; Hidalgo et al. 2009; McCabe and Clark 2005; Rajagopalan et al. 2009; Regonda et al. 
2005; Stewart et al. 2005). Accompanying these changes is evidence for a higher proportion of precipitation falling as rain rather than snow (Knowles et al. 2006), increasingly low baseflows during dry years (Luce and Holden 2009), and significant increases in the percentage of total water year (WY) discharge occurring during the winter (Das et al. 2009; Dettinger and Cayan 1995; Stewart et al. 2005).

Numerous studies have identified increases in winter and spring minimum temperatures $T_{\min }$ linked to greenhouse gas (GHG)-induced global warming as the primary drivers of hydrologic change in snow-dominated areas of western North America (Barnett et al. 2008; Clow 2010; Dettinger et al. 2004; Hamlet et al. 2007; Knowles and Cayan 2004; Regonda et al. 2005; Stewart et al. 2005). However, the suite of observed hydroclimatic changes within a particular region or location also incorporates complex relationships between localized weather events and synoptic- to hemisphericscale forcings (e.g., regional land cover change to ocean-atmosphere teleconnections). For example, over interannual-to-decadal time scales the seasonal controls on hydroclimatic variability and change are strongly influenced by natural ocean-atmosphere interactions extending from the tropical and North Pacific Ocean (e.g., Cayan 1996; Cayan et al. 1998; Dettinger et al. 1994; Rood et al. 2005), with modifying influences associated with the North Atlantic (e.g., Enfield et al. 2001; McCabe et al. 2004). Variations in sea surface temperatures (SSTs) substantially alter air temperature and precipitation patterns across large regions (i.e., at subcontinental scales) by modifying atmospheric circulation patterns and consequently changing the preferential positioning of storm tracks (Cayan 1996; Cayan et al. 1998; Dettinger et al. 1994). For the northern Rocky Mountains (NRMs), the Pacific decadal oscillation (PDO; Mantua et al. 1997) is the dominant interannual-to-decadal-scale index of Pacific basin sea surface temperature variability in this regard because it integrates high- and low-frequency information from both the tropical $\mathrm{Pa}$ cific and North Atlantic-though the specific mechanisms are still being explored (e.g., Dong et al. 2006; Enfield et al. 2001; McCabe et al. 2008; Zhang and Delworth 2007).

In mountainous regions, studies seeking to understand hydroclimatic variability and trends are further complicated by the influence of topography on climate (Das et al. 2009; Karoly and Wu 2005; Pederson et al. 2010; Rauscher et al. 2008). One common approach to detection and attribution studies in the western United States has been to examine average conditions over relatively large spatial domains (usually many 1000s10000 s of square kilometers), but this invariably masks local-to-regional-scale (100s-1000s of square kilometers) variations and trends that may be critical for water and natural resource management. This is particularly true in that local-to-regional variability and change may differ from the patterns that are observed or predicted at continental-to-subcontinental scales (Das et al. 2009; Pederson et al. 2010). As a result, disentangling the relative influence of regional warming and other drivers on the amount and timing of snowmelt and related streamflow processes can be enormously difficult. This complexity necessitates the close examination of a wide range of observational data from multiple hydroclimaticmonitoring networks.

In this study, we assess historic variability and trends in the hydroclimatology of snow-dominated watersheds in the NRMs (Fig. 1), defined here to include the U.S. northern Rocky Mountains and the southern Canadian Rocky Mountains. In addition, we examine the role of regional- and synoptic-scale drivers, as well as remote forcings, as controls on hydroclimatic variability and change within these watersheds. This study is motivated by increasing pressure on state and federal resource management agencies to incorporate this type of climate information into sustainability- and adaptation-planning efforts (Rocky Mountain Climate Working Group 2010). The NRM region is particularly suitable for this type of study because it contains a number of the longestrunning, high-resolution snow observation stations in North America, as well as a suite of long-duration, highquality records from stream gauges and meteorological stations (METs). Understanding the drivers of hydroclimatic variability and change in this region is critical for several reasons: 1) the NRMs encompass the transboundary Crown of the Continent Ecosystem (Fig. 1), 2) they form a key headwaters for three of North America's largest river systems (i.e., the Columbia, Missouri, and South Saskatchewan Rivers), and 3) the region also contains the world's first International Peace Park [collectively Glacier (United States) and Waterton Lakes National Parks (Canada) — -which is also the United Nations Educational, Scientific and Cultural Organization (UNESCO) World Heritage Site and arguably one of the most intact and functional temperate ecosystems in the world (Prato and Fagre 2007).

Based on prior research (e.g., Cayan et al. 1998; Das et al. 2009), we expect that the majority of the observed variance in NRM peak and total annual snowpack and streamflow arises from changes in synoptic-scale drivers [e.g., PDO, El Niño-Southern Oscillation (ENSO), with attendant changes in atmospheric circulation) with a minor, but significant, influence of regional surface temperatures. As for changes in the timing of hydrologic events [i.e., snowmelt, snow cover duration, streamflow 


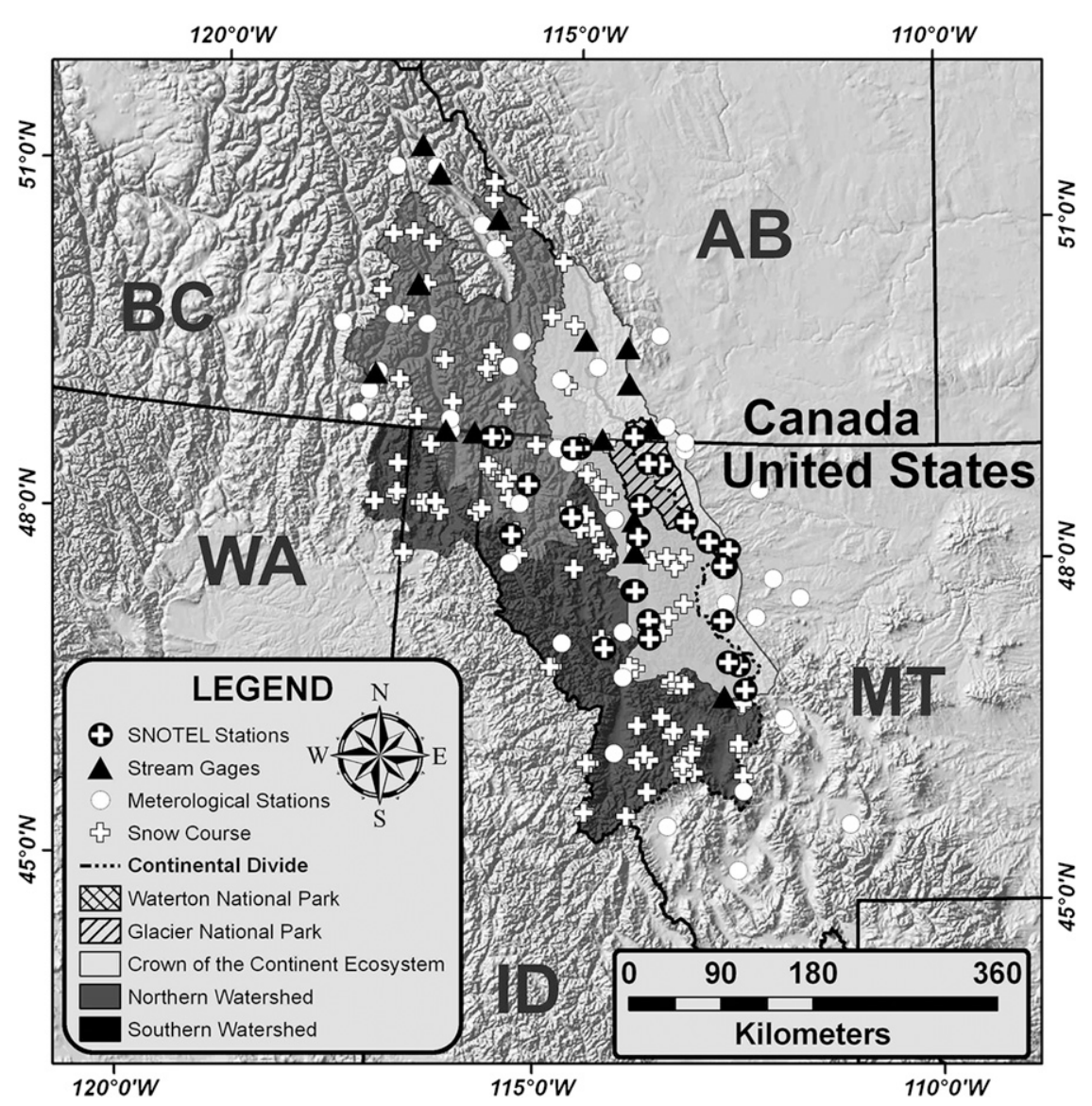

FIG. 1. Map of the NRM study region and SNOTEL $(n=25)$, snow course $(n=148)$, stream gauge $(n=14)$, and valley METs $(n=37)$ used in this study.

center-of-mass timing (CT)], we expect observed trends and variability to be strongly controlled by surface temperature. In this paper, we specifically diagnose changes within, and covariability between, climatic and hydroclimatic time series from individual stations and regionwide averages. In particular, we examine relations between snow cover duration and SWE along with associated changes in streamflow discharge. We also detail changes in low- to midelevation temperatures [including the number of frost days $\left.\left(\leq 0^{\circ} \mathrm{C}\right)\right]$, along with linkages to snowmelt and streamflow timing. Finally, we examine connections between long-term hydroclimatic changes (i.e., amount and timing) and ocean-atmosphere teleconnections.

\section{Data and methods}

The study region was first divided into two subwatersheds based on U.S. Geological Survey (USGS) watershed units (Hydrologic Unit Maps; Seaber et al. 1987) and snow telemetry (SNOTEL), and then snow course records providing the broadest spatial coverage were selected for analyses (Fig. 1). SNOTEL stations provided the daily records of SWE and collocated temperature loggers used in high-resolution assessments of changing snow dynamics, whereas 1 April SWE records from snow course measurements provided longterm, coarse-resolution estimates of peak SWE for extended record comparisons. SWE and temperature data were initially obtained from 37 SNOTEL stations in the U.S. and Canadian portions of the NRM study region. Although other Canadian hydroclimatic records were used, the 12 Canadian SNOTEL records were excluded from further analyses because long reporting intervals ( $\geq 5$ days) and numerous data gaps precluded their use in generating the daily statistics. The remaining 25 records (Fig. 1, Table 1) are taken from Natural Resource Conservation Service (NRCS; available online at http://www.wcc.nrcs.usda.gov/snow/) SNOTEL stations in western Montana. The selected SNOTEL records contained a minimum of $15 \mathrm{yr}$ of daily data, the longest of which extends back to 1969-the networks earliest observations. Stations are located at an average elevation of 1743 MSL ( $\pm \sigma 259 \mathrm{~m}$; Table 1$)$, making this 
TABLE 1. SNOTEL station locations, elevation, percentage of record available, and start year.

\begin{tabular}{|c|c|c|c|c|c|c|c|}
\hline SNOTEL site & Elev (m) & $\begin{array}{c}\text { Snowpillow } \\
\text { start year (WY) }\end{array}$ & $\begin{array}{l}\text { SWE record } \\
\text { available }(\%)\end{array}$ & $\begin{array}{c}\text { Temperature } \\
\text { start year (WY) }\end{array}$ & $\begin{array}{c}\text { Temperature record } \\
\text { available }(\%)\end{array}$ & Lat & Lon \\
\hline Garver Creek & 1295 & 1969 & 100 & 1997 & 100 & $48^{\circ} 58^{\prime} \mathrm{N}$ & $115^{\circ} 49^{\prime} \mathrm{W}$ \\
\hline Grave Creek & 1311 & 1976 & 100 & 1991 & 100 & $48^{\circ} 54^{\prime} \mathrm{N}$ & $114^{\circ} 46^{\prime} \mathrm{W}$ \\
\hline Emery Creek & 1326 & 1977 & 100 & 1990 & 100 & $48^{\circ} 26^{\prime} \mathrm{N}$ & $113^{\circ} 56^{\prime} \mathrm{W}$ \\
\hline Kraft Creek & 1448 & 1981 & 100 & 1991 & 100 & $47^{\circ} 25^{\prime} \mathrm{N}$ & $113^{\circ} 46^{\prime} \mathrm{W}$ \\
\hline Many Glacier & 1494 & 1977 & 100 & 1987 & 100 & $48^{\circ} 47^{\prime} \mathrm{N}$ & $113^{\circ} 40^{\prime} \mathrm{W}$ \\
\hline Bisson Creek & 1500 & 1990 & 100 & 1993 & 100 & $47^{\circ} 41^{\prime} \mathrm{N}$ & $113^{\circ} 59^{\prime} \mathrm{W}$ \\
\hline Hand Creek & 1535 & 1977 & 100 & 1983 & 100 & $48^{\circ} 18^{\prime} \mathrm{N}$ & $114^{\circ} 50^{\prime} \mathrm{W}$ \\
\hline Poorman Creek & 1554 & 1969 & 100 & 1999 & 100 & $48^{\circ} 07^{\prime} \mathrm{N}$ & $115^{\circ} 37^{\prime} \mathrm{W}$ \\
\hline Copper Bottom & 1585 & 1976 & 100 & 2004 & 100 & $47^{\circ} 03^{\prime} \mathrm{N}$ & $112^{\circ} 35^{\prime} \mathrm{W}$ \\
\hline Banfield Mountajin & 1707 & 1969 & 100 & 1989 & 100 & $48^{\circ} 34^{\prime} \mathrm{N}$ & $115^{\circ} 26^{\prime} \mathrm{W}$ \\
\hline Waldron & 1707 & 1969 & 100 & 1990 & 100 & $47^{\circ} 55^{\prime} \mathrm{N}$ & $112^{\circ} 47^{\prime} \mathrm{W}$ \\
\hline Dupuyer Creek & 1753 & 1984 & 100 & 1985 & 100 & $48^{\circ} 04^{\prime} \mathrm{N}$ & $112^{\circ} 45^{\prime} \mathrm{W}$ \\
\hline Pike Creek & 1807 & 1977 & 100 & 1989 & 100 & $48^{\circ} 18^{\prime} \mathrm{N}$ & $113^{\circ} 19^{\prime} \mathrm{W}$ \\
\hline Wood Creek & 1817 & 1979 & 100 & 1990 & 100 & $47^{\circ} 26^{\prime} \mathrm{N}$ & $112^{\circ} 48^{\prime} \mathrm{W}$ \\
\hline Stahl Peak & 1838 & 1976 & 100 & 1990 & 100 & $48^{\circ} 54^{\prime} \mathrm{N}$ & $114^{\circ} 51^{\prime} \mathrm{W}$ \\
\hline Noisy Basin & 1841 & 1975 & 100 & 1990 & 100 & $48^{\circ} 09^{\prime} \mathrm{N}$ & $113^{\circ} 56^{\prime} \mathrm{W}$ \\
\hline Sleeping Woman & 1875 & 1990 & 100 & 1993 & 99.8 & $47^{\circ} 10^{\prime} \mathrm{N}$ & $114^{\circ} 20^{\prime} \mathrm{W}$ \\
\hline Flattop Mountain & 1920 & 1970 & 100 & 1983 & 99.3 & $48^{\circ} 48^{\prime} \mathrm{N}$ & $113^{\circ} 51^{\prime} \mathrm{W}$ \\
\hline North Fork Jocko & 1929 & 1990 & 100 & 1990 & 100 & $47^{\circ} 16^{\prime} \mathrm{N}$ & $113^{\circ} 45^{\prime} \mathrm{W}$ \\
\hline Mount Lockhart & 1951 & 1969 & 100 & 1989 & 100 & $47^{\circ} 55^{\prime} \mathrm{N}$ & $112^{\circ} 49^{\prime} \mathrm{W}$ \\
\hline Hawkins Lake & 1966 & 1969 & 100 & 1989 & 100 & $48^{\circ} 58^{\prime} \mathrm{N}$ & $115^{\circ} 57^{\prime} \mathrm{W}$ \\
\hline Moss Peak & 2067 & 1986 & 100 & 1990 & 100 & $47^{\circ} 41^{\prime} \mathrm{N}$ & $113^{\circ} 57^{\prime} \mathrm{W}$ \\
\hline Badger Pass & 2103 & 1979 & 100 & 1989 & 100 & $48^{\circ} 08^{\prime} \mathrm{N}$ & $113^{\circ} 01^{\prime} \mathrm{W}$ \\
\hline Copper Camp & 2118 & 1976 & 100 & 2004 & 99.9 & $47^{\circ} 05^{\prime} \mathrm{N}$ & $112^{\circ} 43^{\prime} \mathrm{W}$ \\
\hline Nevada Ridge & 2140 & 1994 & 100 & 1995 & 100 & $46^{\circ} 50^{\prime} \mathrm{N}$ & $112^{\circ} 30^{\prime} \mathrm{W}$ \\
\hline Mean & 1743 & & & & & & \\
\hline Median & 1807 & & & & & & \\
\hline Std dev & 259 & & & & & & \\
\hline Max & 2140 & & & & & & \\
\hline Min & 1295 & & & & & & \\
\hline
\end{tabular}

the highest-elevation hydroclimatic-observing network in the NRMs. It should be noted, however, that significant land area without any systematic monitoring exists above many of these sites. Owing to the high reliability and statistically rigorous infilling by NRCS (Schaefer and Paetzold 2010), all of the selected SNOTEL stations offer serially complete daily SWE records. Daily SNOTEL temperature records began in 1983 with an average completeness of greater than $99 \%$. Unlike records of SWE, SNOTEL temperature data have not undergone infilling of missing data but in all cases records contained greater than $99 \%$ of the daily observations.

Daily SNOTEL SWE data were used in analyses of snowpack dynamics throughout the WY (which spans 1 October-30 September). For all daily SWE records the following metrics were calculated: 1 ) day of peak SWE; 2) peak SWE amount; 3) number of snow accumulation and ablation days; 4) snow-free date; 5) number of snowfree days; and 6) length of ablation period (number of days between peak and zero SWE). Snow was said to accumulate (ablate) when gains (losses) exceeded $0.5 \mathrm{~cm}$ for the day, and a site was considered snow-free once measurable SWE fell below instrumentation detection limits $(\approx 0.3-0.5 \mathrm{~cm})$. Daily SNOTEL temperature records were compiled into seasonal and annual time series of $T_{\min }$ and maximum temperature $T_{\max }$. In addition, numbers of days at or below $0^{\circ} \mathrm{C}$ (frost days) were tallied for winter [January-March (JFM)], AMJ, JAS, OND, and the WY. These seasonal breakdowns were chosen to capture the relatively late arrival of spring and summer in the NRMs. Individual station temperature and SWE records were then checked for matching variance, standardized (based on unit variance) against the regional mean, and combined to form a regional composite average (see Pederson et al. 2010).

To provide additional, long-term perspective on the SNOTEL peak SWE observations, we obtained 148 manually measured snow course records from the NRCS and the British Columbia and Alberta Ministry of the Environment (available online at http://www.gov.bc.ca/ pub/mss/; http://www.environment.alberta.ca/apps/basins/ default.aspx) sites (Fig. 1). These records consisted of 1 April SWE observations and cover both major watersheds within our study area. The dataset incorporated 
TABLE 2. Stream gauge station identifier (ID), name, location, percentage of record present, and start year.

\begin{tabular}{|c|c|c|c|c|c|c|}
\hline Stream gauge station ID & Stream gauge station name & State/province & Start year (WY) & Lat & Lon & Record available (\%) \\
\hline 12358500 & MF Flathead River & MT & 1940 & $48^{\circ} 17^{\prime} \mathrm{N}$ & $114^{\circ} 00^{\prime} \mathrm{W}$ & 100 \\
\hline 12355000 & Flathead at BC Border & MT & 1946 & $49^{\circ} 00^{\prime} \mathrm{N}$ & $114^{\circ} 28^{\prime} \mathrm{W}$ & 92.7 \\
\hline 12370000 & Swan River & MT & 1923 & $48^{\circ} 01^{\prime} \mathrm{N}$ & $113^{\circ} 05^{\prime} \mathrm{W}$ & 98.7 \\
\hline 08NH006 & Moyie River & ID & 1916 & $49^{\circ} 00^{\prime} \mathrm{N}$ & $116^{\circ} 10^{\prime} \mathrm{W}$ & 100 \\
\hline $08 \mathrm{NH} 032$ & Boundary Creek & ID & 1930 & $49^{\circ} 00^{\prime} \mathrm{N}$ & $116^{\circ} 34^{\prime} \mathrm{W}$ & 98.7 \\
\hline 08NA002 & Columbia River at Nicholson & $\mathrm{BC}$ & 1917 & $51^{\circ} 14^{\prime} \mathrm{N}$ & $116^{\circ} 54^{\prime} \mathrm{W}$ & 98.9 \\
\hline 08NB005 & Columbia River at Donald & $\mathrm{BC}$ & 1946 & $51^{\circ} 28^{\prime} \mathrm{N}$ & $117^{\circ} 10^{\prime} \mathrm{W}$ & 100 \\
\hline 08NF001 & Kootenay River & $\mathrm{BC}$ & 1941 & $50^{\circ} 53^{\prime} \mathrm{N}$ & $116^{\circ} 02^{\prime} \mathrm{W}$ & 100 \\
\hline 08NJ013 & Slocan River & $\mathrm{BC}$ & 1915 & $49^{\circ} 27^{\prime} \mathrm{N}$ & $117^{\circ} 33^{\prime} \mathrm{W}$ & 100 \\
\hline 08NK016 & Elk River & $\mathrm{BC}$ & 1950 & $49^{\circ} 52^{\prime} \mathrm{N}$ & $114^{\circ} 45^{\prime} \mathrm{W}$ & 98.2 \\
\hline 08NH007 & Lardeau River & $\mathrm{BC}$ & 1946 & $50^{\circ} 15^{\prime} \mathrm{N}$ & $117^{\circ} 04^{\prime} \mathrm{W}$ & 90.8 \\
\hline 05AA022 & Castle River & $\mathrm{AB}$ & 1946 & $49^{\circ} 30^{\prime} \mathrm{N}$ & $114^{\circ} 08^{\prime} \mathrm{W}$ & 100 \\
\hline 05AA023 & Oldman River & $\mathrm{AB}$ & 1950 & $49^{\circ} 48^{\prime} \mathrm{N}$ & $114^{\circ} 10^{\prime} \mathrm{W}$ & 100 \\
\hline $05 \mathrm{AD} 003$ & Waterton River & $\mathrm{AB}$ & 1910 & $49^{\circ} 06^{\prime} \mathrm{N}$ & $113^{\circ} 50^{\prime} \mathrm{W}$ & 100 \\
\hline
\end{tabular}

all records with at least $30 \mathrm{yr}$ of 1 April SWE measurements, with some records spanning the entire recording period from 1936 to 2007. Records within each watershed were normalized (converted to $z$ scores) and subsequently averaged to produce a time series of mean 1 April SWE anomalies for both watersheds. These regional 1 April SWE time series were then used as independent verification of observed patterns in the selected SNOTEL records, as well as in analyses of relationships with stream discharge and synoptic-scale controls.

Stream discharge data were obtained from 14 gauges in both the U.S. and Canadian portions of the study area (Fig. 1, Table 2). The selected stream gauge records were minimally influenced by human activities (Moore et al. 2007; Rood et al. 2005) and began on or before 1952 with greater than $90 \%$ of the daily observations. The following metrics were then calculated from the daily streamflow time series: 1) amount and timing of peak discharge; 2) total WY discharge; 3) day of $50 \%$ cumulative discharge (CT); 4) day of $75 \%$ cumulative discharge; and 5) time elapsed between dates of $50 \%$ and $75 \%$ cumulative discharge. As in previous studies (e.g., McCabe and Clark 2005, Stewart et al. 2005; Clow 2010), we use the WY day at which $50 \%$ of the cumulative streamflow discharge has passed the stream gauge, or CT, as our primary metric for snowmelt-driven streamflow timing. In addition to the analysis of CT, we also investigate changes in WY day of $75 \%$ cumulative discharge for evidence of changes in time elapsed between snowmelt-driven peak flows as they decline toward summer baseflows. Individual gauge time series for each of these variables were subsequently combined into regional composite averages using the same techniques that were applied to the SNOTEL and snow course records. Stream discharge data were obtained from the U.S. Geological Survey (available online at http://waterdata.usgs.gov/nwis) and Environment Canada's Hydrometric Program (available online at http:// www.wsc.ec.gc.ca/applications/H2O/index-eng.cfm).

Monthly temperature and precipitation data were obtained from 37 METs within the study area (Fig. 1), and they were used to assess long-term, watershed-level changes in climate and potential elevation-related differences in temperature variability and trends. We first developed regional-average precipitation series from 37 sites, using the same techniques applied to the snow course records. Next, we incorporate a previously developed regional time series of $T_{\max }$ and $T_{\min }$ from a subset of nine stations used in a previous analysis of changes in regional temperature means and extremes (Pederson et al. 2010). We limited our regional time series to this subset because the selected daily and monthly MET records are high quality and relatively serially complete back to 1895 ( $\geq 97 \%$ of daily observations present). Additionally, the trends and variability captured by this subset of nine stations match those from a network of 15 stations extending farther north into the Canadian Rockies (see Watson et al. 2008). MET data were obtained from the U.S. Historic Climatology Network (USHCN; Menne et al. 2009; available online at http://cdiac.ornl.gov/epubs/ndp/ushen/ newushcn.html) and the Historic Canadian Climate Database (HCCD; Mekis and Hogg 1999, available online at http://www.cccma.bc.ec.gc.ca/hccd/) because these stations generally provide the longest and most complete temperature and precipitation records available. Monthly data from these networks have also been corrected for time-of-observation biases, station moves, instrument changes, and urban heat island effects (Karl et al. 1988; Mekis and Hogg 1999; Menne and Williams 2005; Vincent et al. 2002). All instrumental climatic data series, derived 
hydroclimatic variables (e.g., center-of-mass timing, $T_{\min }$ days below $0^{\circ} \mathrm{C}$ ), and final figures will be served from the USGS Northern Rocky Mountain Science Center Web site (available online at http://nrmsc.usgs.gov/ NRMsnowmelt).

We tested the resulting snowpack, precipitation, temperature, and streamflow regional-mean time series for statistically significant correlations and linear trends using parametric Pearson correlation coefficients and linear bivariate least squares regression (including quadratic terms) coupled with analysis of variance. If the parametric assumptions of constant variance, normal distribution (Kolmogorov-Smirnov test), and lack of autocorrelation in residuals (Durban-Watson test) were not met, nonparametric Mann-Kendall regression and rank correlation tests were performed and reported. Nonparametric regression provides a robust approach if assumptions of parametric regression were not met, which can be a problem with hydrologic time series (Rood et al. 2005).

To assess the impact of large-scale oceanic and atmospheric variability on regional changes in snowpack and streamflow, we calculated correlations between regional hydroclimatic variables and 1) time series of key Pacific basin climate indices (listed below) and 2) 1000250-mb geopotential height and wind fields $(500-\mathrm{mb}$ results shown). Prior research has shown a strong regional influence of the PDO, and to a lesser degree ENSO, on 1 April SWE (Cayan 1996; Cayan et al. 1998; Mote 2003; Mote et al. 2005; Pederson et al. 2004; Selkowitz et al. 2002). We revisit these relationships using monthly SST values and winter season averages of the PDO obtained from the Joint Institute for the Study of Atmosphere and Ocean at the University of Washington (available online at http://jisao.washington.edu/pdo/PDO. latest), and the Niño-3.4 index from the National Oceanic and Atmospheric Administration (NOAA)/ Earth System Research Laboratory (ESRL; available online at http://www.cgd.ucar.edu/cas/catalog/climind/ TNI_N34/index.html). Monthly geopotential height and wind fields were obtained from the National Centers for Environmental Prediction (NCEP) reanalysis project (Kalnay et al. 1996).

To further assess Pacific basin influences on regional hydroclimatic variables, we constructed best-fit least squares linear regression models using stepwise and bestsubsets regression procedures on significantly correlated $(p \leq 0.05)$ seasonal and monthly Pacific basin SST indices and regional MET observations. Relative to dynamical prediction, this method provides a simple diagnostic tool in assessing the bulk impact of major modes of climate system variability on regional hydroclimate. To ensure highly consistent results, predictor variables were selected

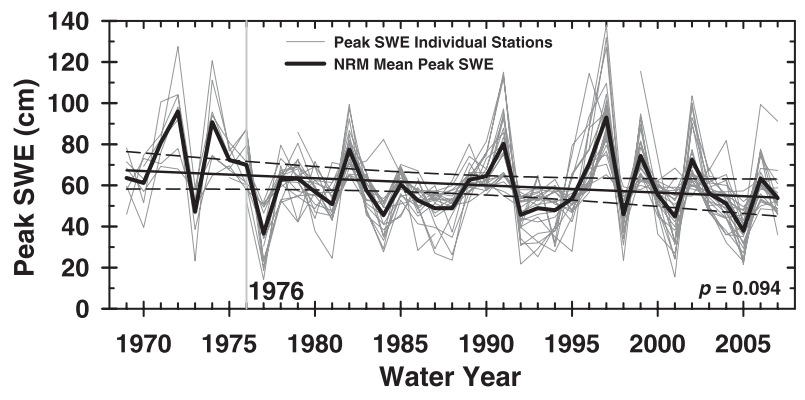

FIG. 2. Average peak SWE calculated from 25 stations (black line). Values are plotted as anomalies from regional SWE mean and individual station records are plotted (gray lines). A regression line (black solid line) shows trends in SWE and is bounded by $95 \%$ confidence intervals (black dashed lines) with significance ( $p$ value) shown.

based on a suite of model diagnostics that include the adjusted $R^{2}\left(R^{2}\right.$ adj), validation $R^{2}$, Mallow's $\mathrm{C}_{p}$, rootmean-square error, and a leave-one-out cross-validation [Predicted Residual Sum of Squares (PRESS)] procedure (Draper and Smith 1998). Linear models were constructed iteratively, meaning that at each step the influence of the predictor was subtracted from the predictand, leaving a residual time series on which to regress the next most strongly correlated predictor. The construction of final models excluded the ENSO index because ENSO and PDO covary on interannual time scales due to tropical and extratropical interactions (An et al. 2007; Newman et al. 2003), consequently violating linearmodeling assumptions.

\section{Results and discussion}

\section{a. Changes in snowpack (snow water equivalent) and streamflow}

Examination of the 25 individual SNOTEL records indicates marked temporal coherency in snowpack variability across the study area (Fig. 2). As represented by amount of peak SWE, stations in both the northern and southern watersheds and throughout the entire elevation range show consistently low snowpack in years such as 1977, 1995, and 2005 and high snowpack in 1972, 1974, and 1997. Likewise, patterns of variability at individual stations tend to agree strongly with regional-average peak SWE.

Further analysis of regional peak SWE (from SNOTEL) suggests a small linear decline in snowpack $(p=0.09)$ over the period 1969-2007 (Fig. 2). There has been ample documentation in many parts of the western United States for a loss of snowpack since the midtwentieth century (e.g., Hamlet et al. 2007; Mote et al. 2005; Pierce et al. 

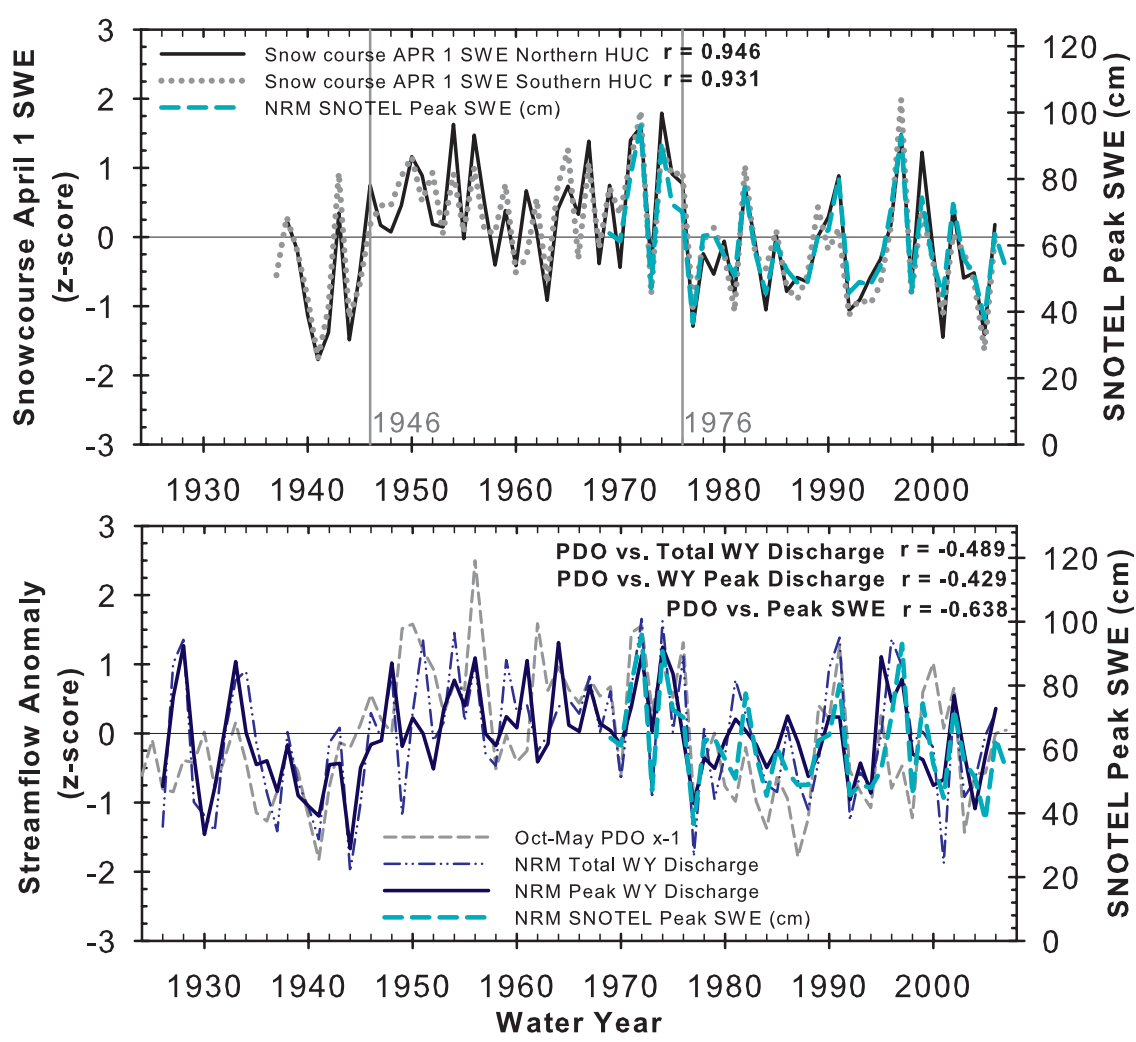

FIG. 3. (top) Comparison between SNOTEL peak SWE and snow course 1 Apr SWE records. (bottom) Relationship between winter season PDO (October-May), total WY stream discharge, peak WY stream discharge, and peak SWE. Note that the PDO was inverted (multiplied by -1$)$ for ease of comparison, and all correlations are significant $(p \leq 0.05)$.

2008), and our results indicate some agreement with these previous studies. However, any trend in our study area is embedded within short records containing pronounced interannual variability. Visual inspection of Fig. 2 also suggests a possible step change from predominantly high to low snowpack conditions around 1976 (see Fig. 3 and paragraph below for supporting evidence), followed by several multiyear periods with lower than average snowpack through the mid-1990s. Overall, a complex mix of large interannual fluctuations combined with potential decadal-scale variability and a slight downward trend characterizes peak SWE variability in the NRMs.

Records of snow course 1 April SWE compiled for both the northern and southern NRM watersheds show the composite time series are good metrics of SNOTEL peak SWE, and that since 1936 a major feature of the records is the strong variability on interannual- to decadal scales that coincides with changes in streamflow discharge (Fig. 3). The temporally consistent signal of regional snowpack variability is underscored by the strong and significant $(p \leq 0.001)$ relationships between SNOTEL peak SWE and snow course 1 April SWE, with correlations of $r=0.946$ and $r=0.931$ for the northern and southern subwatersheds, respectively. Results are supportive of previous research showing that throughout the Rocky Mountains measurement-related errors between record types are typically constrained to $12 \%$ or less (Bohr and Aguado 2001). Because snowpack is the primary driver of runoff in the NRMs, regional-average SWE should also correlate strongly with streamflow for the region. The correlation between 1 April SWE and peak and total annual discharge (Fig. 3, bottom) is in fact strong $(r=0.687$ and $r=0.756$, respectively) and highly significant ( $p \leq 0.001)$. We therefore further use these records to examine the longer-term dynamics and climatic controls on the snowmelt-driven hydrology in the NRMs.

Returning to the short, but high-resolution, SNOTEL records we examine snowpack dynamics throughout the WY, and Fig. 4 shows significant changes in the timing of peak and zero SWE. As in previous studies showing the progressively earlier meltout of snow at midelevations (e.g., Hamlet et al. 2007; Pierce et al. 2008; Clow 2010), records for the NRMs show that since 1969 SWE peaks on average 9 days earlier in the WY $(p=0.04)$ with an 


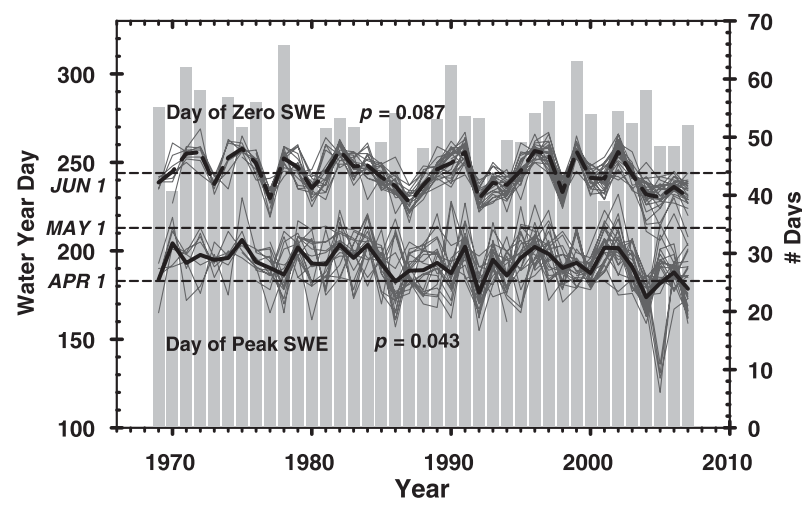

FIG. 4. Regional-average timing of peak SWE (black dashed line) and zero SWE (black solid line). Melt-period duration (gray bars) shows the number of days elapsed between day of peak and zero SWE. All time series are plotted as anomalies from regional mean, individual station records are plotted as dark gray lines, and significance of trend ( $p$ value) is shown, though the regression line is not plotted. Strong interannual and within-year station-to-station variability exists for day of peak SWE, which is likely a function of topography and other local site characteristics influencing snow accumulation (e.g., wind) combined with the inherent spatial heterogeneity of snowfall. Interannual variability in the day of zero SWE is also high, but station-to-station variability is small since snowmelt is largely temperature driven.

8-day progression toward earlier meltoff $(p=0.09)$ as shown by the WY day of zero SWE. Accordingly, the change in elapsed time between peak and zero SWE is nonsignificant. The regional trend equates to a shift from peak SWE generally occurring between 15 and 20 April in the early portion of the record (1969-84) to peak SWE occurring on or before 1 April in recent years.

SNOTEL records also suggest high interannual and intrasite variability in the number of winter storm events and snow ablation days, with both metrics showing nonsignificant long-term linear trends (Fig. 5, top and middle). The number of SWE accumulation days corresponds positively with regional peak SWE anomalies, and therefore it may serve as a proxy for the frequency of storm events. This suggests that over the 1969-2007 period storm-track position is a major interannual-todecadal-scale control on the total amount of peak SWE received in the NRMs, but it fails to account for the longterm, negative linear trend in peak SWE (Fig. 2). The most likely explanation of drivers behind the long-term negative trend in peak SWE is increasing DJF and MAM temperatures (Fig. 6). Controls on ablation are generally more complex than accumulation owing to topography, with variability in the number of ablation days through time tied to both sublimation and temperature-induced melting.

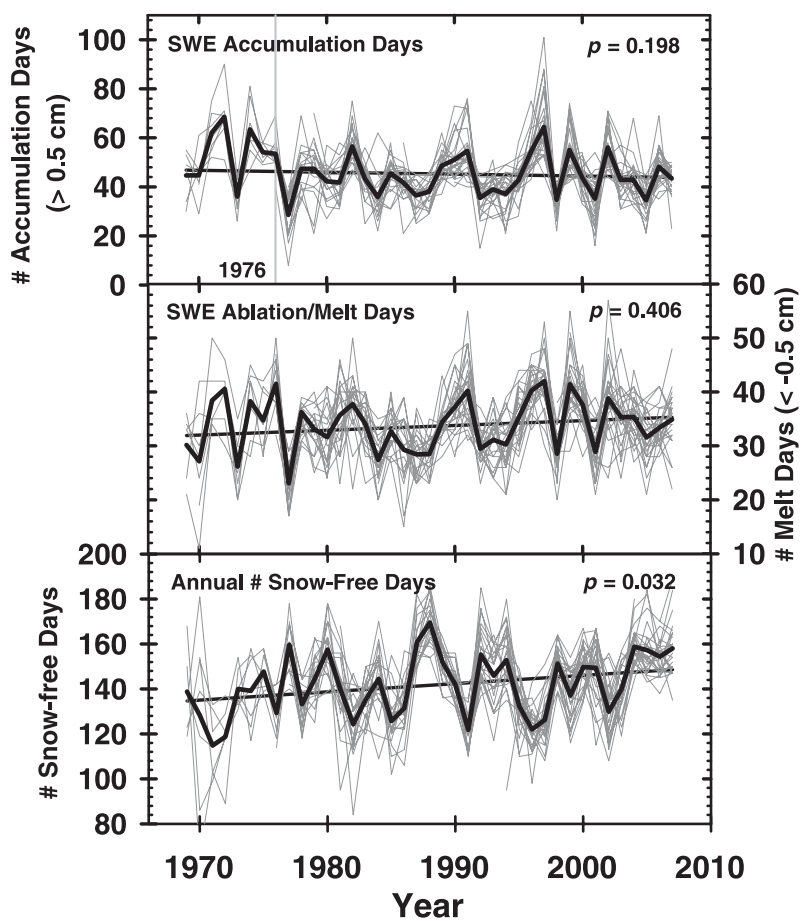

FIG. 5. Average annual number of SWE (top) accumulation days, (middle) ablation days, and (bottom) snow-free days recorded at SNOTEL stations. All time series are plotted as anomalies from regional mean, individual station records are plotted as dark gray lines, and trends are shown with a black regression line with significance of trend ( $p$ value) shown.

Lastly, SNOTEL records exhibit significant changes in snow cover duration, as shown by the increasing number of snow-free days per year over time. Figure 5 (bottom) shows that the number of snow-free days has increased significantly ( $p=0.032)$, with the NRMs showing an average loss of 14 days of snow cover between 1969 and 2007. With the majority of the increase in the number of snow-free days apparent in the spring (8-day increase), it follows that spring and early summer temperatures should be strongly linked to the observed trend. However, total winter snowfall, total peak SWE, and the timing of major storm events could also play an important role in dictating the annual number of snowfree days (see discussion below).

\section{b. Impacts of regional temperature and precipitation change on snowpack and streamflow}

\section{1) Mid-TO-High-Elevation temperature CHANGE}

Mid-to-high-elevation SNOTEL stations within the NRMs show a coherent and significant increase $(p \leq$ $0.05)$ in average winter, spring, and annual $T_{\min }$ since the early 1980s (Fig. 6). METs representing valley sites also 


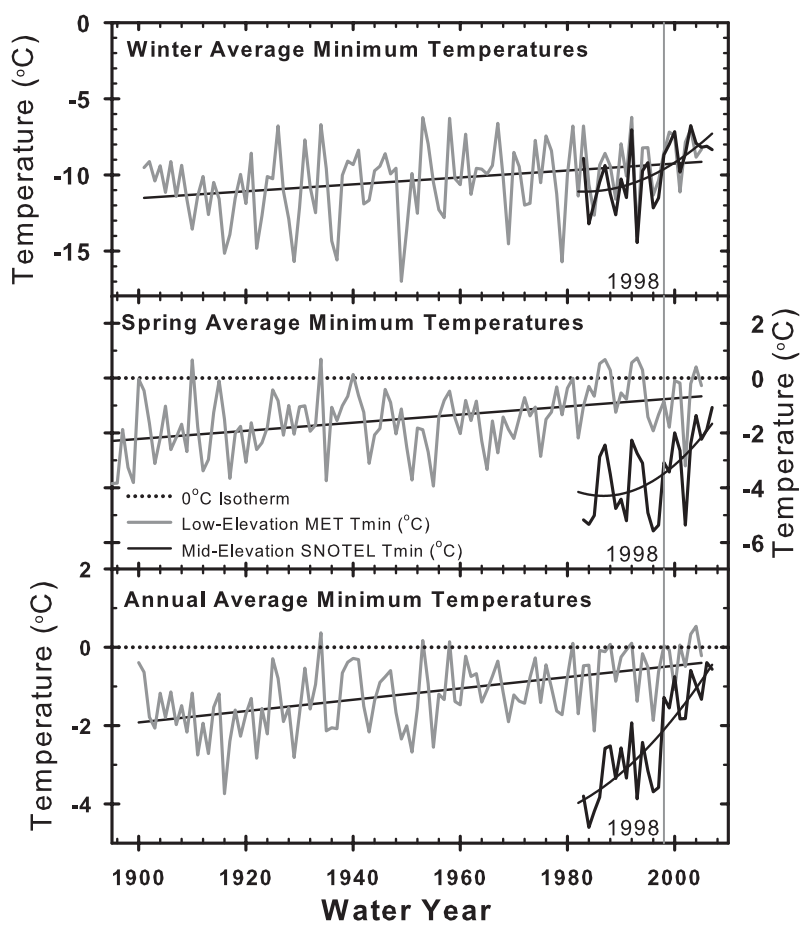

FIG. 6. Average (top) winter (December-February), (middle) spring (March-May), and (bottom) annual minimum temperatures from SNOTEL stations (WY, October-September) and valley METs (calendar year, January-December). SNOTEL station $T_{\min }$ records have been fit using a nonlinear quadratic equation due to characteristics of these time series. All trends shown are significant $(p \leq 0.05)$, and note that the $y$-axis temperature scale changes for each panel.

show significant increases in $T_{\min }$ over the twentieth century, though the recent trend magnitude is smaller than at SNOTEL sites (Fig. A1). Estimates of the magnitude of trend for the regional composite time series of SNOTEL $T_{\min }$ shown in Fig. 6 are based on quadratic regression since results provide a slightly more conservative estimate than obtained from simple linear regression models. Results show that since 1983 average $T_{\min }$ at SNOTEL stations has increased over DJF by $+3.8^{\circ} \pm 1.72^{\circ} \mathrm{C}$, MAM by $+2.5^{\circ} \pm 1.23^{\circ} \mathrm{C}$, and annually by $+3.5^{\circ} \pm 0.73^{\circ} \mathrm{C}$ (Fig. 5) - which is consistent with findings from other studies using temperature data from SNOTEL- and satellite-based Microwave Sounding Units (Clow 2010; Diaz and Eischeid 2007). Note the short, highly variable nature of these time series prevents us from accurately estimating the underlying trend. The temperature records do not, however, span any shifts in known large-scale modes of decadal variability, which could further amplify the trend. Hence, the greater magnitude of midelevation warming likely reflects a response to both regional low-elevation warming and elevation-dependent responses.
Minimum temperatures at SNOTEL stations display interannual variability similar in magnitude to valley METs with the exception of spring minimums. Spring $T_{\min }$ records generally exhibit approximately twice the variance of minimum temperatures observed at valley METs and more rapid recent warming. Average spring $T_{\text {min }}$ approaches the $0^{\circ} \mathrm{C}$ frost threshold during years of early snowmelt and severe growing season drought (e.g., $1988,1998,2000,2001$, and 2003), with the warmest years coming toward the end of the record. Midwinter and average annual $T_{\min }$ observations from SNOTEL stations also show more rapid recent warming, with a pronounced increase after 1998 that is consistent across individual station records (not shown). Though recent warming has been rapid, winter $T_{\min }$ remain $\approx 8^{\circ} \mathrm{C}$ below freezing. Similar to observations at valley METs, however, average annual $T_{\min }$ appears to be rapidly approaching $0^{\circ} \mathrm{C}$.

Changes in average seasonal lapse rates and surface albedo are two potential drivers for the high variability and recent enhanced upward trend in observed SNOTEL temperatures. While again recognizing the limitations of analyzing short time series, a post-1983 comparison of trends from low-elevation MET records against SNOTEL observations suggests regional lapse rates may be changing (Fig. 6 and Fig. A1). Supportive of this finding, Diaz and Eischeid (2007) have shown significant changes in lapse rates and more rapid warming of the higher elevations across the western United States using SNOTEL- and satellite-based Microwave Sounding Unit observations. Additionally, the increase in average annual $T_{\min }$ and, to some degree winter and spring $T_{\min }$, does coincide with the major 1998 El Niño event (Enfield 2001) and a recent perceived slowing of average global temperature rise (Thompson et al. 2008).

The high interannual variability and trend shown in the spring $T_{\min }$ record suggests feedback processes associated with reduced surface albedo may also be a significant factor. This expectation is supported by nested regional climate-modeling results from Rauscher et al. (2008), showing that with reduced snow cover and changed surface albedo the greatest rates of warming should be expected in the mid- to high elevations. Reduced surface albedo would result from the observed earlier snowmeltout (Fig. 4) and the increasing number of snow-free days (Fig. 5, bottom). As discussed below, the average WY day of zero SWE and number of snow-free days is itself controlled by a number of factors ranging from total winter snowfall and variability in the timing of end-of-season storm events because of spring atmospheric circulation patterns-all of which undoubtedly adds to the interannual variability in SNOTEL temperature records.

Concurrent with the increase in seasonal and annual SNOTEL $T_{\min }$, we show a substantial decline in the 

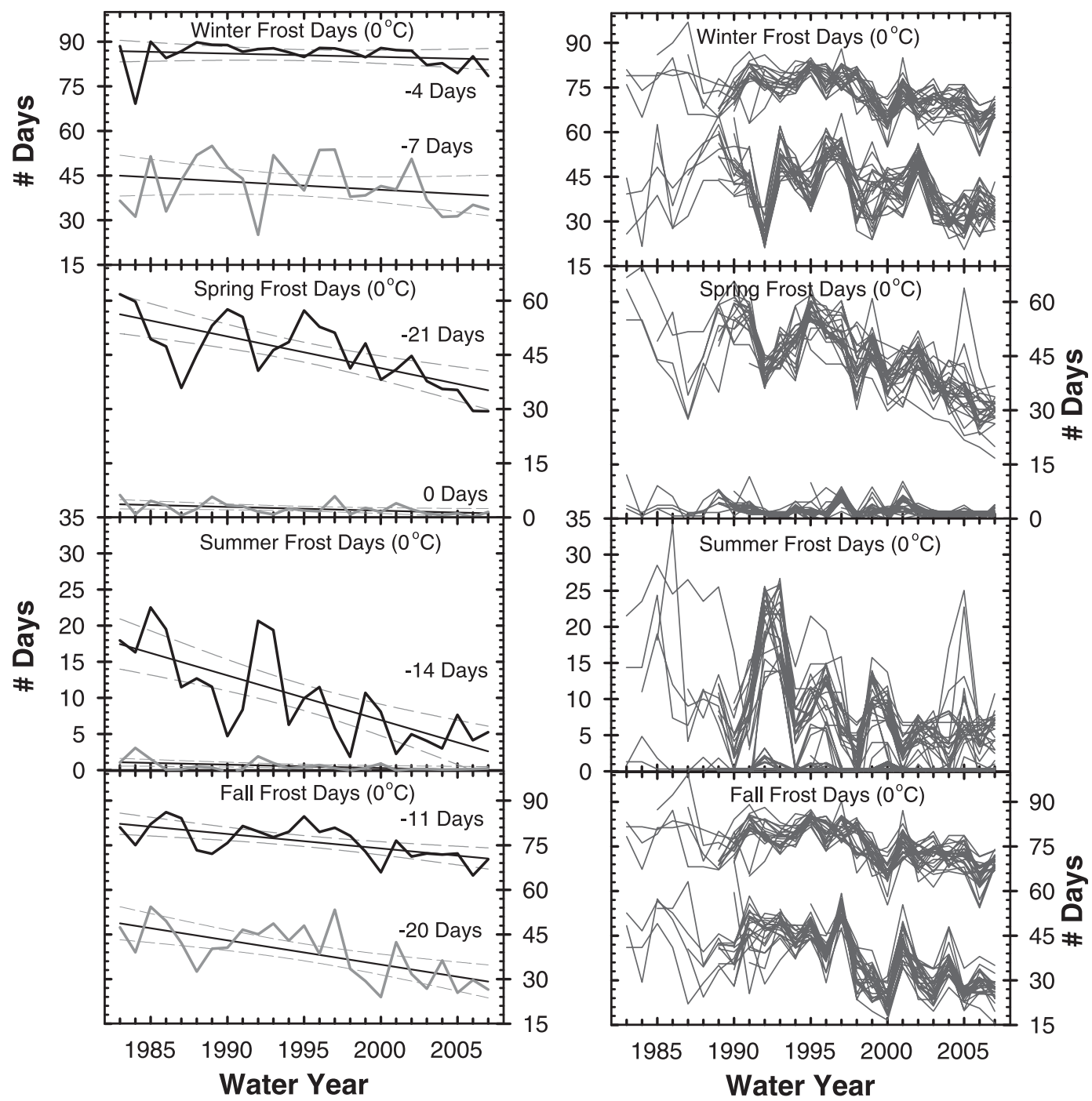

FIG. 7. (left) Regional average and (right) individual station records (gray lines) showing the number of frost days (days $\leq 0^{\circ} \mathrm{C}$ ) for $T_{\max }$ (gray lines) and $T_{\min }$ (black lines) recorded at all SNOTEL stations over JFM, AMJ, JAS, and OND. All time series are plotted as anomalies from regional mean, and all trends are significant (except for the trends in spring and summer $T_{\max } ; p \leq 0.001$ ) and shown with a black regression line bracketed by $95 \%$ confidence intervals (gray dashed lines). Reduction in number of freeze/thaw days (calculated from the trend lines) from 1983 to 2007 is printed to the right of each average time series.

number of days per year below the $0^{\circ} \mathrm{C}$ threshold. Figure 7 (left) shows a significant $(p \leq 0.001)$ reduction in regional average number of days with $T_{\min } \leq 0^{\circ} \mathrm{C}$ across JFM, AMJ, JAS, and OND-with the caveat that these are short records. The regional average for the number of days with $T_{\max } \leq 0^{\circ} \mathrm{C}$ also shows a significant drop over the winter and fall. Individual station records for both $T_{\min }$ and $T_{\max }$ (Fig. 7, right) show strong coherency, thereby reducing the potential for outlying years or single-station records to be responsible for driving the observed trends in loss of frost days. Over the 25-yr period of record, the smallest reductions in the number of days with $T_{\max }$ or $T_{\min } \leq 0^{\circ} \mathrm{C}$ are seen over the winter, with this season showing an average reduction of 7 and 4 days $\leq 0^{\circ} \mathrm{C}$, respectively. Spring and summer generally feature few daytime $T_{\max }$ values below freezing; however, nighttime $T_{\min }$ shows a dramatic loss of days below $0^{\circ} \mathrm{C}$. Since 1983 , the number of spring $T_{\min }$ days $\leq 0^{\circ} \mathrm{C}$ have declined by an average of 21 days, now approaching only approximately 30 days where nighttime $T_{\min }$ falls below $0^{\circ} \mathrm{C}$. Similarly, the summer has lost an average of 14 days where $T_{\min }$ drops below $0^{\circ} \mathrm{C}$, and it is now rapidly approaching average conditions whereby summer frost events rarely occur at the average elevation of 

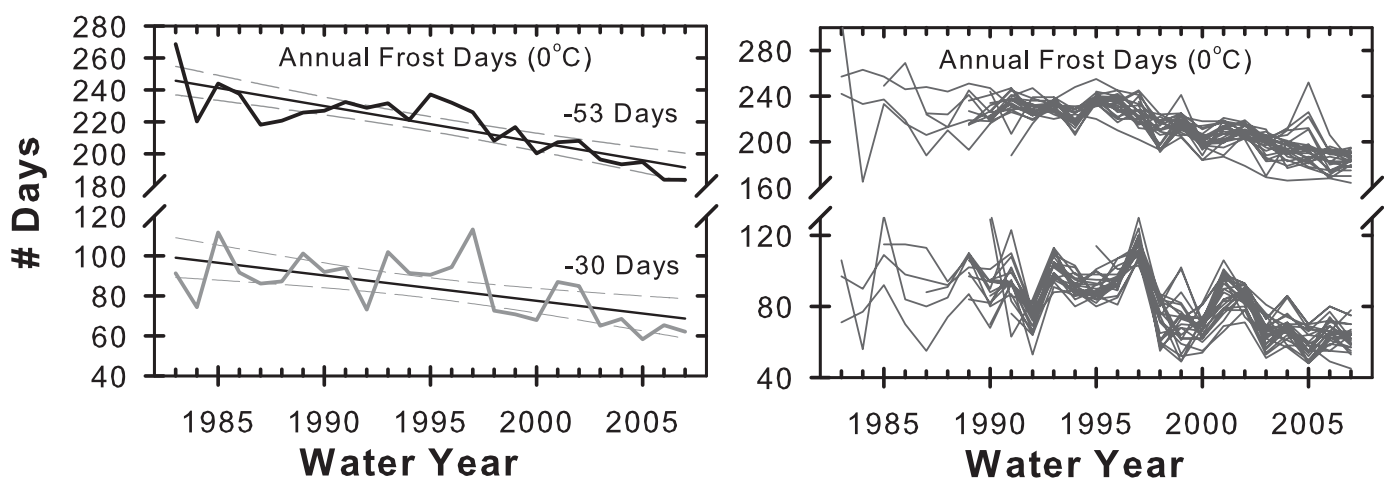

FIG. 8. As in Fig. 7, but for annual average number of frost days (days $\leq 0^{\circ} \mathrm{C}$ ).

the SNOTEL stations $(\approx 1743 \mathrm{~m}$ MSL). Finally, OND records show an average reduction of 11 and 20 days with $T_{\min }$ and $T_{\max }$ below $0^{\circ} \mathrm{C}$, respectively.

Summed across the entire WY, we document an average loss of 53 days with $T_{\min } \leq 0^{\circ} \mathrm{C}$ over this 25 -yr period and an average loss of 30 days with $T_{\max } \leq 0^{\circ} \mathrm{C}$ (Fig. 8). NRM valley METs also show a decline in number of days with $T_{\min }$ and $T_{\max } \leq 0^{\circ} \mathrm{C}$ (Pederson et al. 2010), but the recent rate and magnitude of change is noticeably larger at the mid- to higher elevations represented by these SNOTEL records. The combined 35-day loss in $T_{\min }$ frost events over AMJ and JAS months are perhaps the most hydrologically relevant temperature changes since relatively warm nighttime temperatures likely reduce the cold content and refreezing of snowpack. Also, though not explicitly shown here, the documented declines in fall $T_{\max }$ and $T_{\min }$ days $\leq 0^{\circ} \mathrm{C}$ may also be increasingly limiting the early season accumulation of snowpack.

\section{2) TEMPERATURE IMPACTS ON SNOWMELT AND SNOW COVER DURATION}

Further exploring the role of temperature as both a driver and response to regional snowpack dynamics, we compare 1) the regional-average number of snowfree days, and 2) the average day of peak and zero SWE, with temperature records from both SNOTEL and valley METs (Table 3, Fig. 9, top). Both spring and annual $T_{\max }$ and $T_{\min }$ are significantly $(p \leq 0.05)$ correlated with the average number of snow-free days per year $(r=$ $0.434-0.757)$, day of peak SWE ( $r=-0.443$ to -0.756$)$, and day of zero SWE $(r=-0.354$ to -0.820$)$. Correlations are highest when comparing selected snowpackrelated metrics against spring temperatures recorded at SNOTEL stations relative to records from lowerelevation METs. On the whole, these observations support the potential combined impacts of recent, more rapid high-elevation warming and a positive feedback associated with mid-to-higher-elevation albedo changes (Clow 2010; Diaz and Eischeid 2007; Rauscher et al. 2008; Stewart et al. 2005). The influence of total annual SWE on snow cover duration and consequently albedo is likewise captured by the strong negative correlations between the number of snow-free days with SNOTEL peak SWE $(r=$ $-0.689, p \leq 0.001)$ and snow course 1 April SWE $(r=$ -0.617 to $-0.689, p \leq 0.001$ ) shown in Fig. 9 (bottom).

Overall, results are supportive of previous studies (e.g., Clow 2010; Das et al. 2009; Pierce et al. 2008) showing that warmer temperatures (especially minimums) are an important driver behind the increasing number of snow-free days and earlier WY day of peak and zero SWE. Additionally, snowpack and temperature

TABLE 3. Correlations between the average annual number of snow-free days, WY day of peak and zero SWE, and 50\% CT and spring and annual $T_{\max }$ and $T_{\min }$ recorded at valley $(1969-2007, n=39)$ and SNOTEL stations $(1983-2007, n=25)$.

\begin{tabular}{lcccc}
\hline \hline \multicolumn{1}{c}{ Variable } & $\begin{array}{c}\text { No. snow-free } \\
\text { days }(p \text { value })\end{array}$ & $\begin{array}{c}\text { WY day of } \\
\text { peak SWE } \\
(p \text { value })\end{array}$ & $\begin{array}{c}\text { WY day of } \\
\text { zero SWE } \\
(p \text { value })\end{array}$ & $\begin{array}{c}5 \% \% \text { CT } \\
(p \text { value })\end{array}$ \\
\hline SNOTEL spring $T_{\min }$ & $0.718(0.001)$ & $-0.750(0.001)$ & $-0.815(0.001)$ & $-0.567(0.005)$ \\
SNOTEL spring $T_{\max }$ & $0.586(0.003)$ & $-0.709(0.001)$ & $-0.820(0.001)$ & $-0.681(0.001)$ \\
SNOTEL annual $T_{\min }$ & $0.479(0.024)$ & $-0.443(0.039)$ & $-0.375(0.085)$ & $-0.177(0.431)$ \\
SNOTEL annual $T_{\max }$ & $0.757(0.001)$ & $-0.595(0.003)$ & $-0.669(0.001)$ & $-0.640(0.001)$ \\
Spring MET $T_{\min }$ & $0.491(0.002)$ & $-0.615(0.001)$ & $-0.639(0.001)$ & $-0.596(0.001)$ \\
Spring MET $T_{\max }$ & $0.509(0.001)$ & $-0.756(0.001)$ & $-0.766(0.001)$ & $-0.710(0.001)$ \\
Annual MET $T_{\min }$ & $0.434(0.007)$ & $-0.443(0.039)$ & $-0.354(0.031)$ & $-0.184(0.275)$ \\
Annual MET $T_{\max }$ & $0.505(0.001)$ & $-0.595(0.003)$ & $-0.486(0.002)$ & $-0.423(0.009)$ \\
\hline
\end{tabular}



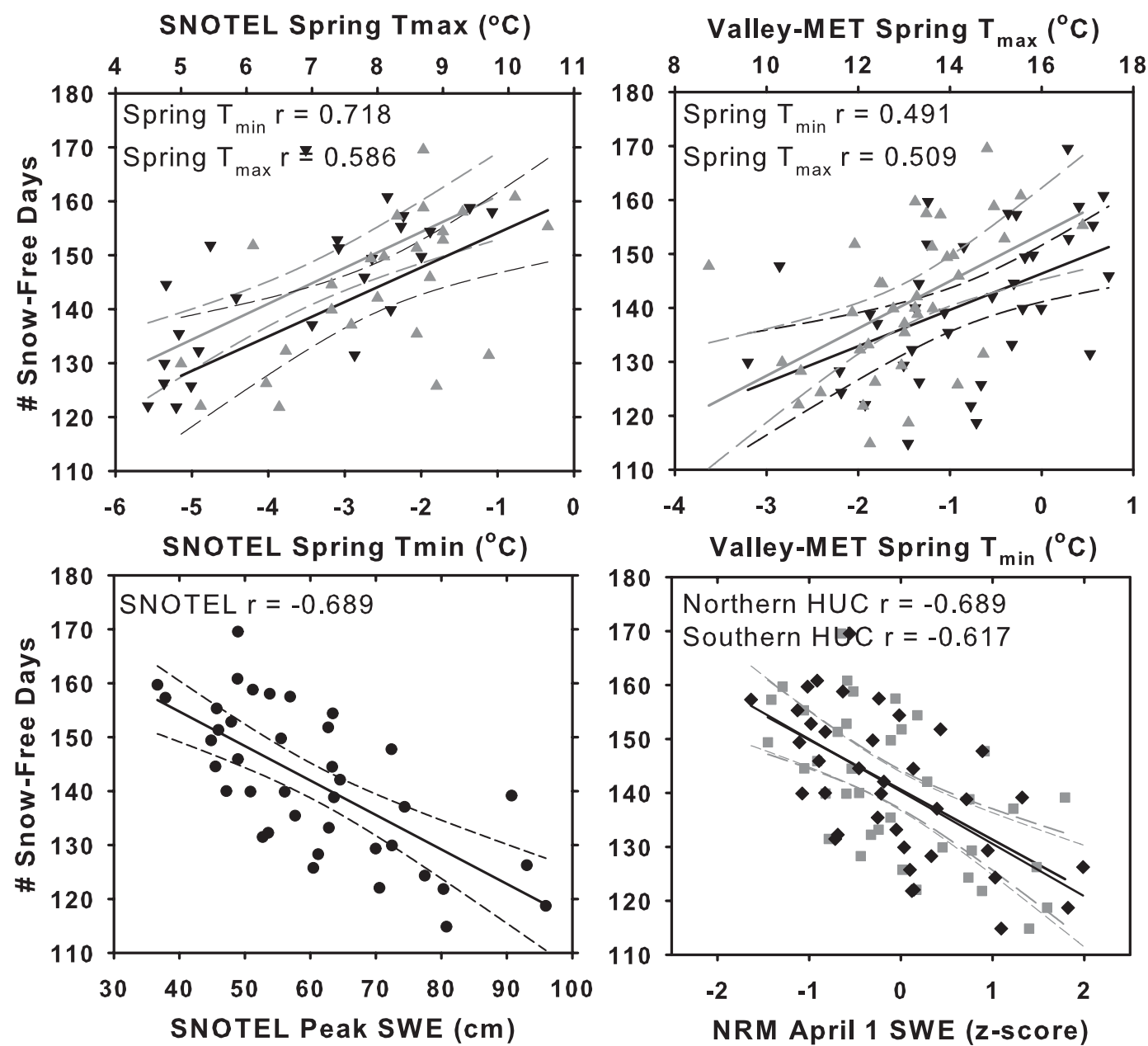

FIG. 9. (top) Correlation between number of snow-free days and average spring $T_{\min }$ (black triangles) and $T_{\max }$ (gray triangles) recorded at (left) SNOTEL stations and (right) valley METs. Also plotted are (bottom) correlations between number of snow-free days and (left) SNOTEL peak SWE and (right) snow course 1 Apr SWE [gray squares = northern hydrologic unit code (HUC), black diamonds = southern HUC]. Regression lines are plotted with corresponding $95 \%$ confidence intervals, and correlations are significant at $p \leq 0.001$ level.

relationships at mid- to higher elevations may be complicated by the influence of low-elevation warming trends (see Pederson et al. 2010) on valley snow cover (see Knowles et al. 2006). Low-elevation warming, subsequent loss of snow cover, and accompanying changes in albedo may, in turn, drive a positive feedback process more rapidly melting snow in the midelevations and further contributing to temperature increases at the elevation of SNOTEL stations. Rapid warming shown at SNOTEL stations would then relate, in part, to the loss of mid-tohigher-elevation snow, with resulting changes in albedo reflected in station-level temperature records.

\section{3) Changes in Surface Climate AND STREAMFLOW TIMING}

Changes in spring temperatures are linked to the regional average of snow-free days and the day of peak and zero SWE in the NRMs, with spring temperatures serving as both a driver and response to these events. In turn, changes in the meltout of snow should be reflected in corresponding changes in the timing of streamflow. Over the period of record, streamflow timing is shown to be highly variable with $\mathrm{CT}$ arriving on or slightly after 1 June, and $75 \%$ of the hydrologic mass passing stream gauges in late June-early July (Fig. 10, top panel). Between 1925 and 1976, however, CT and 75\% cumulative discharge trended toward a later arrival date. After 1976, CT and $75 \%$ cumulative discharge timing show a slight late 1970s and larger mid-1980s tendency toward earlier runoff. The mid-1980s shift to earlier snowmelt runoff is supported by previous studies showing similar shifts in timing of snowmelt runoff across the western United States (e.g., McCabe and Clark 2005), which coincide with increasing spring temperatures associated 

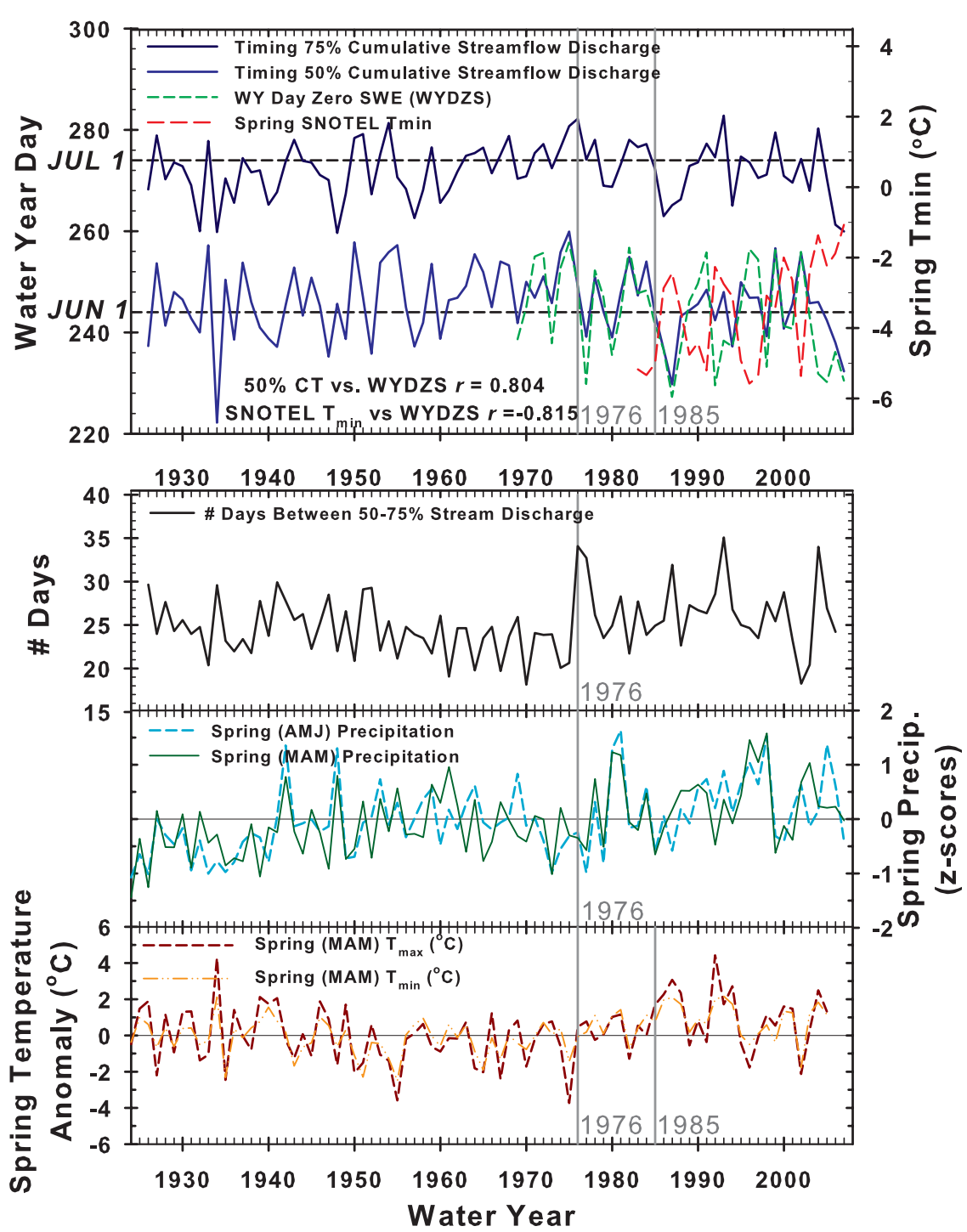

FIG. 10. (top) Timing of 50\% (CT) and 75\% cumulative discharge, day of zero SWE, and SNOTEL average MAM $T_{\text {min. }}$ (bottom) Associated trends, variability, and step changes in elapsed number of days between $50 \%$ and $75 \%$ stream discharge, and average spring precipitation, $T_{\min }$, and $T_{\max }$ for valley METs. Correlations between $50 \% \mathrm{CT}$, spring $T_{\min }, T_{\max }$, and WY day of zero SWE are significant $(p \leq 0.001)$.

with increasing atmospheric heights and thus an earlier onset of spring (Ault et al. 2011; Cayan et al. 2001; Schwartz and Reiter 2000).

NRM regional average CT correlates strongly with the average day of zero SWE $(r=0.804, p \leq 0.001)$, number of snow-free days $(r=-0.518, p \leq 0.001)$, and consequently surface observations of spring $T_{\min }$ and $T_{\max }$ from SNOTEL and valley METs (Fig. 10, Table 3). On the whole, these observations show the strong influence of increasing temperature in driving the earlier meltout of regional snowpack and earlier streamflow CT. Note also that the WY day of zero SWE and streamflow CT are almost exactly the same (Fig. 10, top). This suggests that SNOTEL sites in the NRMs capture the snow-driven portion of regional flows and that SNOTEL records are a good indicator of potential runoff contributions from these basins.

Long-term changes in spring temperature and precipitation are consistent with a late 1970s and mid-1980s progression toward earlier runoff relative to the 1920s through mid-1970s (Fig. 10). The interaction between spring temperature and precipitation is underscored by changes in the number of days between the $50 \%$ (CT) and $75 \%$ discharge points, with the latter being an 
indicator of the transition to summer baseflows. Specifically, after 1976/77 the mean of this time series shifts by 5 days and the variance doubles (Fig. 10, bottom). Whereas before 1976/77 (and after 1940), relatively high spring precipitation and lower spring $T_{\min }$ and $T_{\max }$ corresponded with later CT and fewer days between $50 \%$ and $75 \%$ streamflow discharge. A notable singleyear exception occurred in 1934 during the "Dust Bowl" drought when spring temperature anomalies of $+4^{\circ} \mathrm{C}$ and low spring precipitation resulted in the earliest CT event on record. The late 1970s and mid-1980s transition toward earlier $\mathrm{CT}$, and change in mean and variance of days between $50 \%$ and $75 \%$ stream discharge, corresponds with an increase in mean and variance of total spring precipitation and a period of rapid and sustained spring warming. Overall, results suggest that 1) regional spring temperatures are the dominant driver of streamflow timing and 2) increased variance in spring precipitation may be contributing significantly to high variance in discharge timing since the late 1970s.

\section{c. Synoptic controls on snowpack and streamflow yield and timing}

\section{1) SNOWPACK AND STREAMFLOW YIELD}

A large body of prior research (e.g., see Das et al. 2009 and references therein) has demonstrated that throughout the western United States (e.g., Cayan 1996; Cayan et al. 1998), and within the NRM region specifically (Moore et al. 2007; Mote 2006; Pederson et al. 2004; Rood et al. 2005), variations in SWE and streamflow are affected by interannual and interdecadal changes in the PDO and the interaction of the PDO with ENSO (An et al. 2007; Newman et al. 2003). Using the records compiled here, both cool season (October-May) or winter (November-March) PDO correlates significantly ( $p \leq 0.001)$ with SNOTEL peak SWE at $r=-0.638$, snow course 1 April SWE at $r=-0.693$, total WY discharge at $r=-0.489$, and peak discharge at $r=-0.429$ (Fig. 3). All records show potential shifts in mean occurring in 1945/46 and 1976/77, which is consistent with well-documented interdecadal shifts in sea surface temperature and pressure in the North Pacific Ocean (Fig. 3, bottom). Correlations between peak SWE, streamflow, and winter ENSO are also significant (not shown), though the respective correlation values were roughly half as strong.

Changes in North Pacific SSTs ultimately affect SWE and runoff by altering major modes of atmospheric circulation and consequently the strength and position of the winter westerlies (i.e., preferential storm-track position) across North America (Dettinger et al. 1994). Correlation fields of $500-\mathrm{mb}$ atmospheric heights and winds over the core winter months (JFM) show that for NRM snowpack anomalies there is a broad region of strong positive correlations in the North Pacific centered over the Aleutian Islands and strong negative correlations poleward of $45^{\circ} \mathrm{N}$ (the mean wintertime position of the jet stream) over North America (Figs. 11a,b). This indicates high (low) snowpack anomalies in the NRMs tend to be associated with winter season persistence of high (low) pressure anomalies over the North Pacific basin and low (high) pressure anomalies over most of western North America. These JFM atmospheric circulation patterns reflect the position, persistence, and depth of the Aleutian low, and consequently the preference (or not) for midlatitude cyclones to track from the Gulf of Alaska southeast through the Pacific Northwest and ultimately across the NRMs (Cayan et al. 1998). Accordingly, patterns shown here are consistent with the so-called Pacific-North America (PNA) pattern (Thompson and Wallace 2000), a leading mode of Northern Hemisphere atmospheric variability that is, in part, linked to interannual and decadal changes in PDO and ENSO (Quadrelli and Wallace 2004).

Strong negative correlations between snowpack and the tropical Pacific are seen throughout the winter months (Figs. 11a,b), which is consistent with an ENSO forcing component. These relationships persist through March and April, even as correlations with the North Pacific begin to weaken. The April atmospheric circulation patterns, however, are strongest over western North America and weakened over the tropical Pacific, suggesting regional spring weather plays an important role in dictating total amount of WY peak SWE. Additional 500-mb composites (Figs. A2a,b; Figs. A3a,b) of atmospheric circulation patterns during years with snowpack anomalies \pm 1 standard deviation above or below the long-term mean are supportive of the above results: JFM oceanatmosphere teleconnections control NRM snowpack while spring [March-April (MA)] regional atmospheric circulation anomalies (with links to the tropical Pacific) modulate snowmelt and consequently streamflow. Overall, these results highlight the importance of different seasonal mechanisms driving the amount of cool season precipitation the NRMs receive, with winter season oceanic and atmospheric teleconnections controlling the mean storm track position and interannual to interdecadal variations in SWE and streamflow.

\section{2) SNOWMELT AND STREAMFLOW TIMING}

Atmospheric circulation patterns associated with the meltout of snowpack and timing of streamflow (Figs. $11 \mathrm{c}-\mathrm{e})$ suggest that $\mathrm{CT}$, day of peak and zero SWE (similar to Fig. 11c), and number of snow-free days are most strongly influenced by MAM geopotential heights 


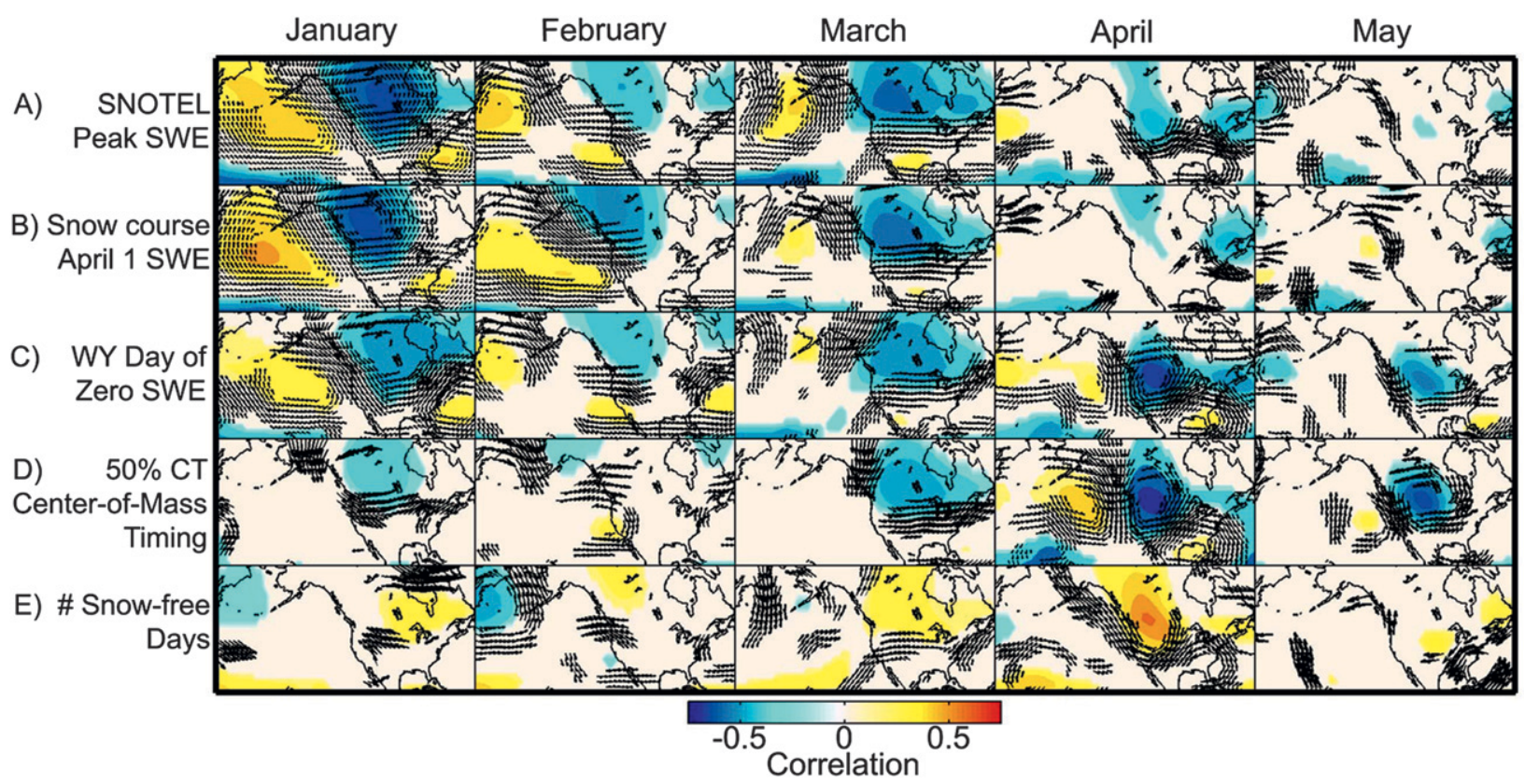

FIG. 11. Field correlations of 500-mb monthly atmospheric pressure and wind anomalies for NRM hydroclimatic variables. Maps are arranged in the following order: (a) SNOTEL peak SWE $(n=39)$, (b) snow course 1 Apr SWE $(n=58)$, (c) day of zero SWE $(n=39)$, (d) day of $50 \%$ CT $(n=58)$, and (e) number of annual snow-free days $(n=39)$. Plotted atmospheric circulation anomalies are significant $(p \leq 0.05)$.

over western North America. The influence of associated circulation patterns becomes evident in March, is strongest in April, and then weakens by May (Figs. 11c-e). Similar 700-mb atmospheric circulation patterns across all spring months (AMJJ) have also been associated with the mid1980s shift toward earlier snowmelt and runoff across the western United States (McCabe and Clark 2005). The April 500-mb correlation fields and composite maps (Figs. A2c-e; Figs A3c-e) also show atmospheric circulation anomalies of opposite sign located off the coast of western North America near $45^{\circ} \mathrm{N}$. Overall, results imply early (late) arrival of CT, or day of zero SWE, is associated with high (low) pressure centered over western North America during the spring (Figs. A1c,d and A2c,d). The same is true for the average number of snow-free days in the NRMs, with Fig. 10e showing that springs characterized by high (low) pressure result in higher (lower) temperatures and more (fewer) snow-free days (Figs. A2e and A3e).

The spring correlation fields and composites also show how the timing of NRM snowmelt and the timing and quantity of streamflow are linked to the tropical (i.e., ENSO) and extratropical (i.e., $\approx 45^{\circ} \mathrm{N}$ ) Pacific (Figs. $11 \mathrm{a}-\mathrm{e})$. These correlations are strongest in months preceding snowmelt and key runoff events, and this lag suggests a modest potential for longer-lead (i.e., seasonal) forecasting of related hydrologic processes across the NRMs. However, substantial variation in this relationship arises due to the influence of atmospheric circulation patterns associated with the end of winter and the transition to spring-like circulation patterns centered over western North America. These respective circulation patterns relate directly to the potential for Arctic air intrusions and moisture delivery from different source areas (e.g., midlatitude Pacific or Gulf of Mexico), and thereby add substantially to variability observed in the timing and amount of snowmelt and streamflow.

\section{d. Exploring the relative impact of key controls on regional snowpack and streamflow}

We have demonstrated that the amount and timing of snowpack and streamflow in the NRMs is linked to 1) wintertime conditions in the Pacific basin via controls on the strength and position of the winter westerlies, and 2) MAM changes in atmospheric circulation and their influence on regional temperature and precipitation anomalies. We now explore the relative influence of these factors using regression-based techniques. Though there is covariability between these drivers, the observed hydroclimatic impacts arise from distinct, seasonally dependent processes (Fig. 11), thus allowing for this type of simple modeling approach. 


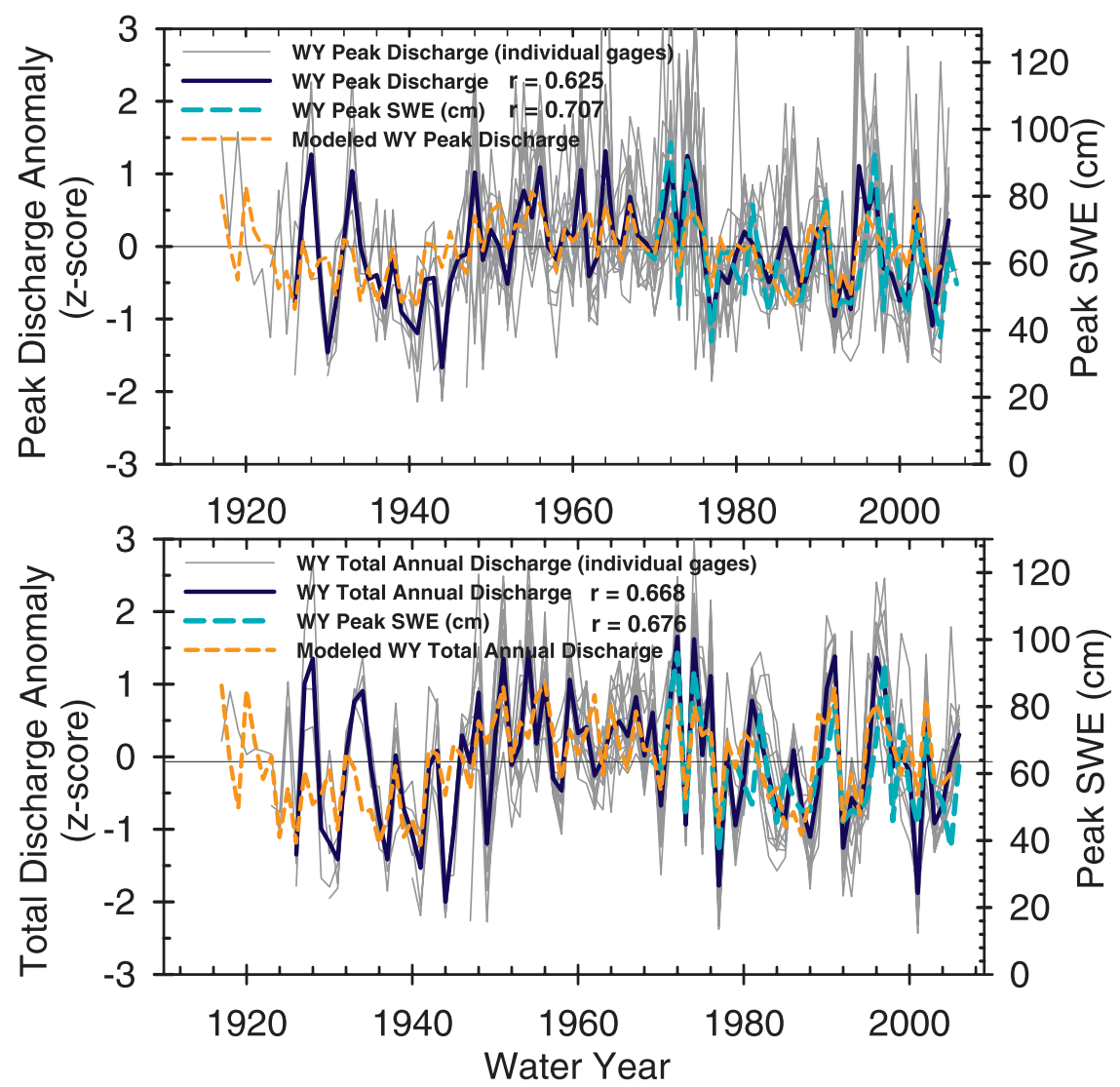

FIG. 12. Final regression models (see run number 3 in Table 4) of peak discharge, total annual discharge, and peak SWE anomalies. Individual stream gauge records are plotted (gray lines). Correlations between observed and modeled time series are significant $(p \leq 0.001)$.

Results show that peak SWE, peak discharge, and total annual discharge can all be adequately modeled using the following three predictors: 1) winter PDO, 2) spring temperature (specifically $T_{\max }$ ), and 3) spring precipitation (Fig. 12, Table 4). We have excluded ENSO from these analyses owing to interactions with PDO and its influence on regional spring temperatures and precipitation. Thus, an ENSO forcing component is implicit in the results shown here. In all models, winter PDO (October-May or November-March) entered as the primary predictor variable, explaining $40.1 \%$ of the variability in peak SWE, $18.4 \%$ in peak streamflow, and $23.9 \%$ of total annual streamflow (Table 4 ). The reduced explanatory power of the PDO in capturing variability in peak flows likely reflects the greater importance of spring weather events, such as rapid warming and precipitation variability (including rain-on-snow events), in driving hydrograph anomalies. The next best-fit variable for snowpack and streamflow was MAM $T_{\max }$ (or $T_{\min }$, either substitutes), which explained an additional $6.9 \%$ to $12.8 \%$ of the observed snowpack and streamflow variability (Table 4). Models for peak SWE and peak stream discharge show a proportionately greater amount of variance explained by spring $T_{\max }$ as compared to models for total annual flows. This may be due to the sensitivity of snowpack and peak streamflow to the timing and magnitude of spring warming, whereas total annual flows integrate the combined influence of recent increases in spring precipitation and temperature.

The addition of MAM precipitation noticeably improves models of peak and annual streamflow, while only marginally contributing to models of peak SWE (Table 4). The relatively small role of spring precipitation in controlling peak SWE may be due in part to the cumulative negative impacts of increasing temperatures on snowpack. Additionally, the inverse trends in NRM snowpack (Fig. 3, top) and spring precipitation (Fig. 10, bottom) may be capturing a shift in the regional rain-to-snow ratio, as previously shown for much of the western United States (Knowles et al. 2006). Likewise, the relatively large proportion of variance explained by spring precipitation in the models of peak and total WY discharge may indicate the increasing influence of precipitation outside the winter months on hydrologic yield 
TABLE 4. Model diagnostics for best-fit least squares linear regression models constructed for peak discharge, total annual discharge, and peak SWE anomalies.

\begin{tabular}{|c|c|c|c|c|c|}
\hline Run & Model & $R^{2}$ & $R^{2}$ adj & $R^{2}$ validation & $p$ value $\leq$ \\
\hline 1 & Peak SWE = $62.6-10.68$ (Oct-May PDO) & 40.6 & 39.0 & 34.7 & 0.001 \\
\hline 2 & $\begin{array}{l}\text { Peak SWE }=106-8.50(\text { Oct-May PDO })-3.32 \\
\quad\left(\text { spring } T_{\max }\right)\end{array}$ & 51.7 & 48.9 & 43.8 & 0.001 \\
\hline 3 & $\begin{array}{l}\text { Peak SWE }=96.5-10.0(\text { Oct-May PDO })-2.67 \\
\quad\left(\text { spring } T_{\max }\right)+5.28[\text { MAM precipitation }(\mathrm{pcp})]\end{array}$ & 55.9 & 51.9 & 45.8 & 0.001 \\
\hline 1 & Peak discharge $=-0.0475-0.313($ Oct-May PDO $)$ & 18.4 & 17.4 & 14.7 & 0.001 \\
\hline 2 & $\begin{array}{l}\text { Peak discharge }=1.90-0.219(\text { Oct-May PDO })-0.154 \\
\quad\left(\text { spring } T_{\max }\right)\end{array}$ & 31.2 & 29.4 & 26.4 & 0.001 \\
\hline 3 & $\begin{array}{l}\text { Peak discharge }=1.49-0.267(\text { Oct-May PDO })-0.122 \\
\quad\left(\text { spring } T_{\max }\right)+0.313(\text { MAM pcp })\end{array}$ & 39.1 & 36.7 & 33.6 & 0.001 \\
\hline 1 & Total discharge $=-0.0766-0.453(\mathrm{Nov}-\mathrm{Mar} \mathrm{PDO})$ & 23.9 & 23.0 & 20.2 & 0.001 \\
\hline 2 & $\begin{array}{l}\text { Total discharge }=1.81-0.381(\text { Nov-Mar PDO })-0.149 \\
\quad\left(\text { spring } T_{\max }\right)\end{array}$ & 30.8 & 29.0 & 25.0 & 0.001 \\
\hline 3 & $\begin{aligned} \text { Total discharge } & =1.15-0.446(\text { Nov}- \text { Mar PDO })-0.0962 \\
\quad\left(\text { spring } T_{\max }\right) & +0.555(\text { MAM pcp })\end{aligned}$ & 44.6 & 42.4 & 38.5 & 0.001 \\
\hline
\end{tabular}

and variance in the NRMs. For the post-1977 period in particular, increases in the amount and variance of spring precipitation may be buffering against changes in the amount and timing of hydrologic flows during years of low snowpack (Figs. 10, 12). Conversely, low spring precipitation would exacerbate these impacts. The implication is that as snowpack melts out of the mountains progressively earlier, summer season streamflow amount and timing has become increasingly dependent on spring precipitation to make up for snow-related deficits.

\section{Summary}

Snowpack in the NRMs serves as a primary source of runoff and hydrologic storage for North American river systems, as well as a key driver of regional biophysical processes. In this work, we first sought to characterize local-to-regional variations and trends in temperature, precipitation, snowpack, and streamflow using observations from a comprehensive hydroclimatic-monitoring network. We then explored the linkages among these variables and examined the role of ocean-atmosphere teleconnections, along with other potential large-scale drivers of snowmelt hydrology. Results related to the characterization of the relevant local-to-regional hydroclimate provide important baseline information on historical variability and change. When combined with our detailed examination of linkages among hydroclimatic variables and potential larger-scale forcings, this study may in turn inform water resource and ecosystem management and help improve regional forecasting and prediction in the face of climate change.

Records from SNOTEL stations show that from 1969 to 2007 the midelevations of the NRMs exhibited a tendency toward decreased regional snowpack, with peak
SWE and meltout arriving an average of 8 days earlier accompanied by an average of 14 fewer days of seasonal snow cover (Fig. 2 and Fig. 4). Though winter (JFM) atmospheric circulation patterns and numbers of winter storm events are tightly linked to peak SWE (Fig. 5 and Figs. 11a,b), a lack of significant long-term trend in these two drivers suggests that other factors must account for snowpack decline. Midelevation temperature records extending back to 1983 show significant seasonal and annual decreases in the numbers of frost days (days $\leq 0^{\circ} \mathrm{C}$ ) and highly variable but increasing minimum temperatures (Figs. 6, 7, and 8). Consistent with expectations, the observed 8 day earlier meltout of snow and 14 additional snow-free days since 1969 are found to covary strongly with streamflow timing (CT) and spring temperatures (Fig. 10).

Strong interannual-to-interdecadal variations are shown for the duration of record for NRM 1 April snowpack and peak and total annual streamflow records (Fig. 3). A substantial proportion $(18 \%-41 \%)$ of this variability in snowpack and streamflow is associated with JFM Pacific basin SST anomalies (i.e., PDO and ENSO) owing to the influence on atmospheric circulation patterns controlling the preferential positioning of winter storm tracks (Figs. 11a,b and Fig. 13a). Winters with high (low) snowpack in the NRMs tend to be associated with negative (positive) PDO conditions, a weakened (strengthened) Aleutian low, and low (high) pressure centered poleward of $45^{\circ} \mathrm{N}$ across western North America (Figs. 13a,b). During years of high snowpack, for example, the tendency is for midlatitude cyclones to track from the Gulf of Alaska southeast through the Pacific Northwest and into the NRMs. The relatively persistent low pressure anomaly centered over western North America is also conducive to more frequent Arctic air outbreaks resulting 
a.
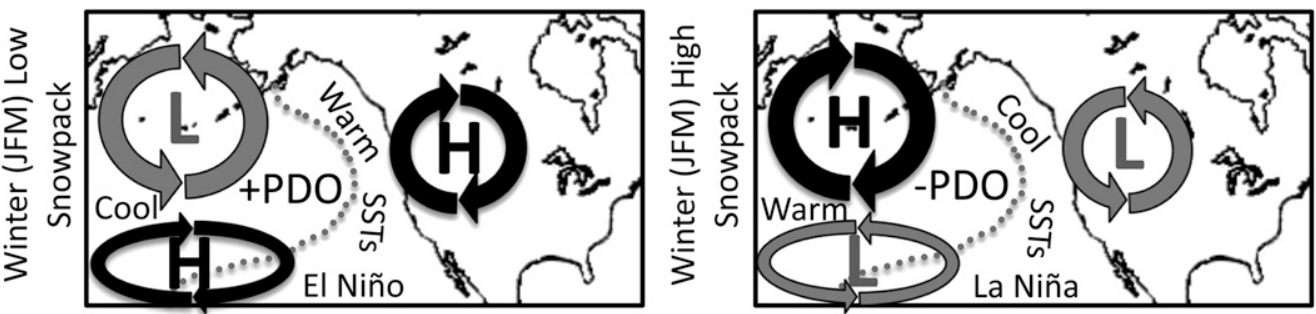

b.
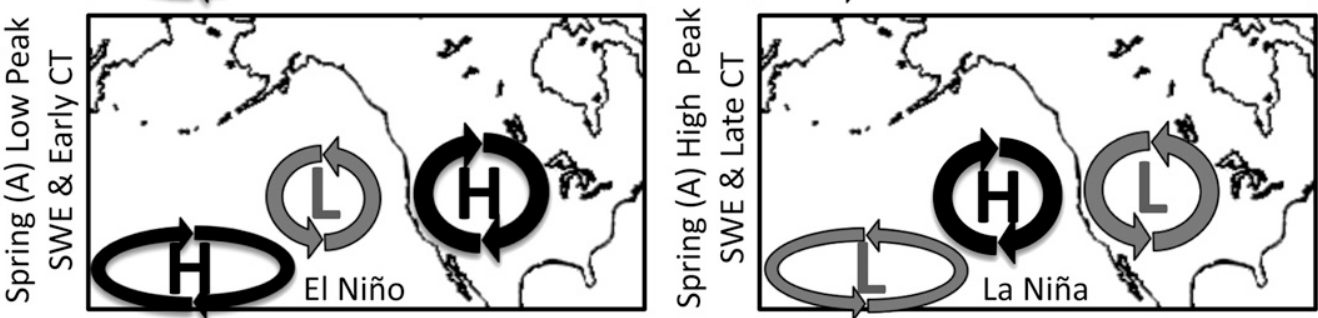

C.
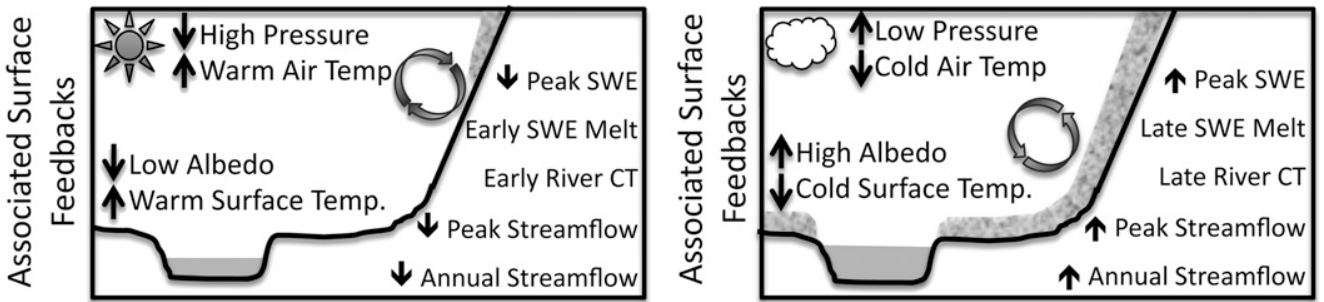

d.
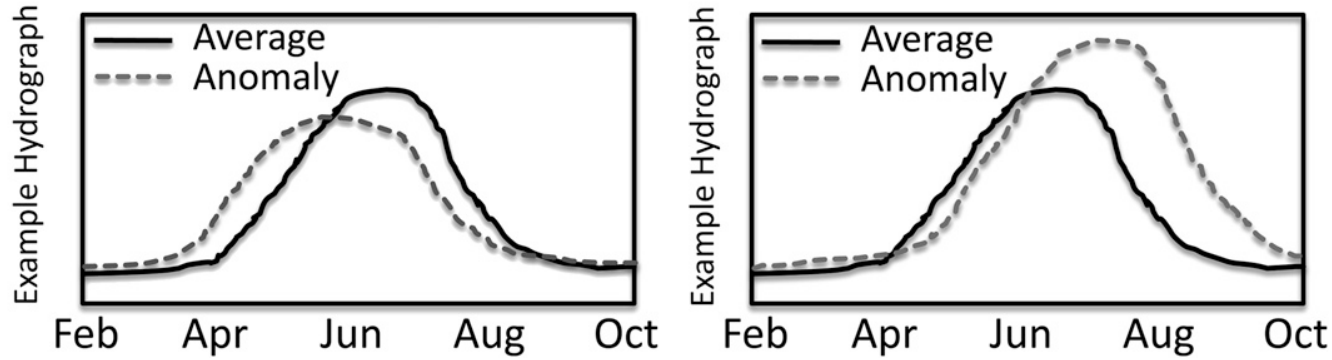

FIG. 13. Idealized relationship between NRM snowpack and streamflow anomalies with associated Pacific SSTs, atmospheric circulation, and surface feedbacks.

in colder winter temperatures. Conditions in the tropical Pacific are also an important driver of snowpack and streamflow at interannual time scales, and the influence of related tropical Pacific atmospheric circulation anomalies persists well into spring (Figs. 11a,b).

Changes in spring (MAM) temperatures and precipitation are associated with changes in regional atmospheric circulation and are shown to strongly influence the timing of NRM streamflow (Figs. 13b-d). Specifically, high (low) pressure anomalies centered over western North America correspond with increased (decreased) spring temperatures and consequently the increasing (decreasing) number of snow-free days, early (late) arrival of snowmeltout, and streamflow CT. Thus, spring atmospheric circulation changes can, in turn, initiate surface feedbacks that contribute to surface temperature and hydrograph anomalies (Figs. 13c,d). The timing of
CT for streams within the NRMs exhibits high variability, with a tendency toward earlier CT dates beginning in the late 1970s and mid-1980s (Fig. 10). Increasing spring precipitation after 1977 appears to buffer streamflow timing from substantially early arrival during what was otherwise a period of low snowpack with above-average temperatures. The more substantial mid-1980s shift toward earlier CT is supportive of findings by McCabe and Clark (2005) and appears to be driven by spring warming associated with greater March-May geopotential heights over western North America (Figs. 11d and 13a,b). Cayan et al. (2001) and Ault et al. (2011) also show that similar March and April atmospheric circulation patterns control multiple phenological and ecological aspects of spring onset across western North America. This, in turn, suggests phenological and ecological changes in the NRMs are likely driven by the same spring atmospheric 
circulation changes and consequently associated with changes in streamflow timing and the duration of snow cover.

Overall, our results agree with past research showing the influence of warming temperatures on earlier snowmelt and runoff, along with decreasing snowpack and streamflow (e.g., Barnett et al. 2008; McCabe and Clark 2005). However, as summarized in Fig. 13, we also show the influence of different seasonally dependent oceanatmosphere teleconnections and atmospheric circulation patterns in driving snowpack and streamflow dynamics. Likewise, this research also points to potential surface-albedo feedbacks that interact with broad-scale controls on snowpack and runoff (Figs. 13c,d); however, more work here is required to disentangle the magnitude of potential influence such surface feedbacks may have. Under future warming scenarios, snowpack throughout the NRMs and other midlatitude regions is expected to decline, with meltout and runoff coming progressively earlier (Adam et al. 2009; Hamlet et al. 2001). Our results imply that if spring precipitation continues to increase in the NRMs, this could offset snow-related declines in streamflow amounts and changes in the timing of snowmelt and runoff to some degree. However, if spring precipitation was to remain at current levels or decline for any reason (e.g., drought or shifting spring storm tracks), we expect a significant amplification of trends toward earlier CT, reduced peak and annual streamflow, and lower (but highly variable) summer baseflows. These expectations are consistent with other regional and global projections of hydroclimatic change over the twenty-first century (Adam et al. 2009; Barnett et al. 2004; Hamlet et al. 2001; Solomon et al. 2007) and have important implications for aquatic and terrestrial ecosystems.

Acknowledgments. This research has benefited from the helpful comments of J. Weiss and J. Betancourt. NSF Grant GSS-0620793 and the USGS Western Mountain Initiative supported this research. Any use of trade, product, or firm names is for descriptive purposes only and does not imply endorsement by the U.S. Government.

\section{APPENDIX}

\section{Supporting Surface Temperature and Atmospheric Control Analyses}

A comparison of post-1983 trends in average minimum surface temperatures recorded at low-elevation METs and midelevation SNOTEL sites provides evidence for greater recent warming at the midelevations (Fig. A1). Figure A1 shows the estimated linear trends from

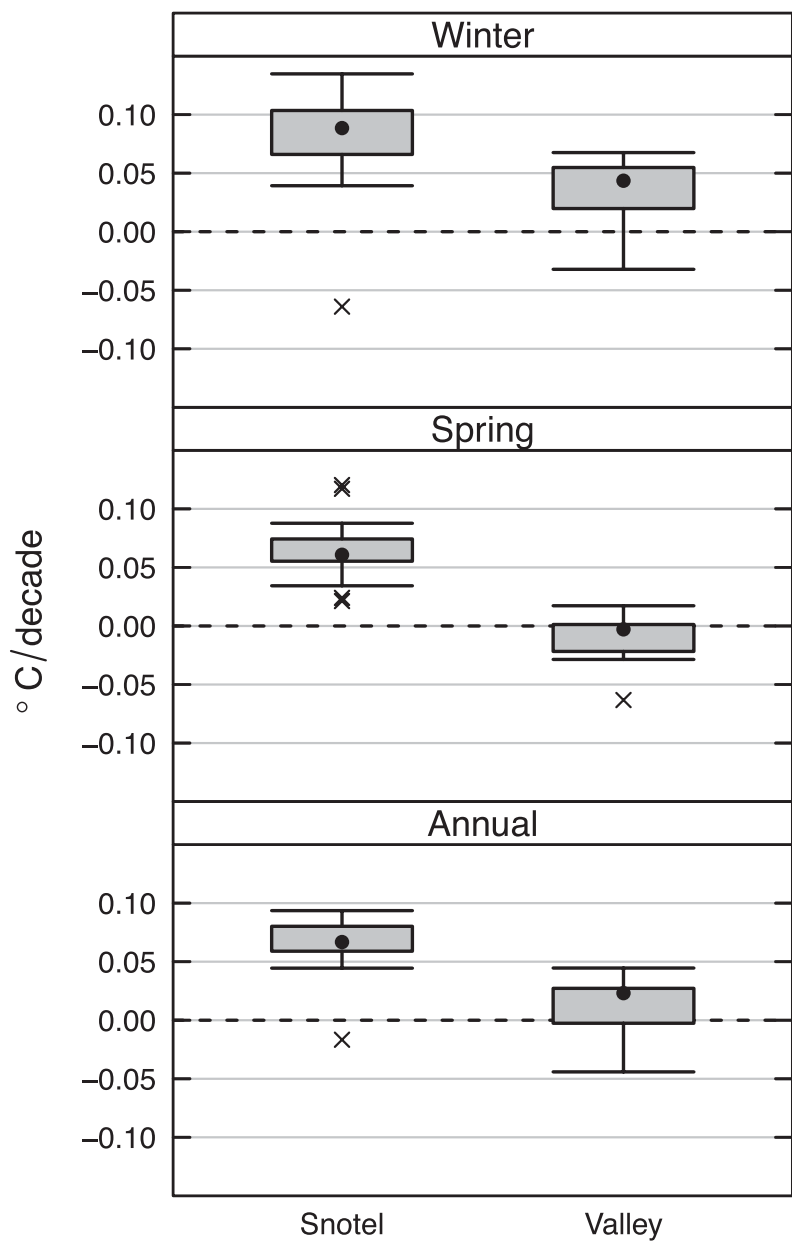

FIG. A1. Post-1983 trends in individual SNOTEL-station and valley MET $T_{\min }$ records.

individual station records spanning 1983-2005 using box plots to illustrate the mean and variance in the estimated temperature change over this common period. Supportive of our conclusions in the main text, results show rates of warming in nighttime minimum temperatures over the winter, spring, and annual averages to be greater at mid- to high elevations. This result is consistent with surface feedbacks associated with the early meltout of snow and reduced snowpack; however, we still urge caution in the interpretation of these short records.

Composite maps of 500-mb pressure and wind anomalies for years of major regional snowpack and streamflow anomalies (i.e., years $\geq$ or $\leq 1 \sigma$; Figs. A2 and A3) are supportive of the identified seasonal atmospheric circulation patterns controlling the amount and timing of snowpack and streamflow anomalies shown using field correlations in Fig. 11. Specifically, years of high regional snowpack conditions $(\geq 1 \sigma)$ are defined by high pressure 


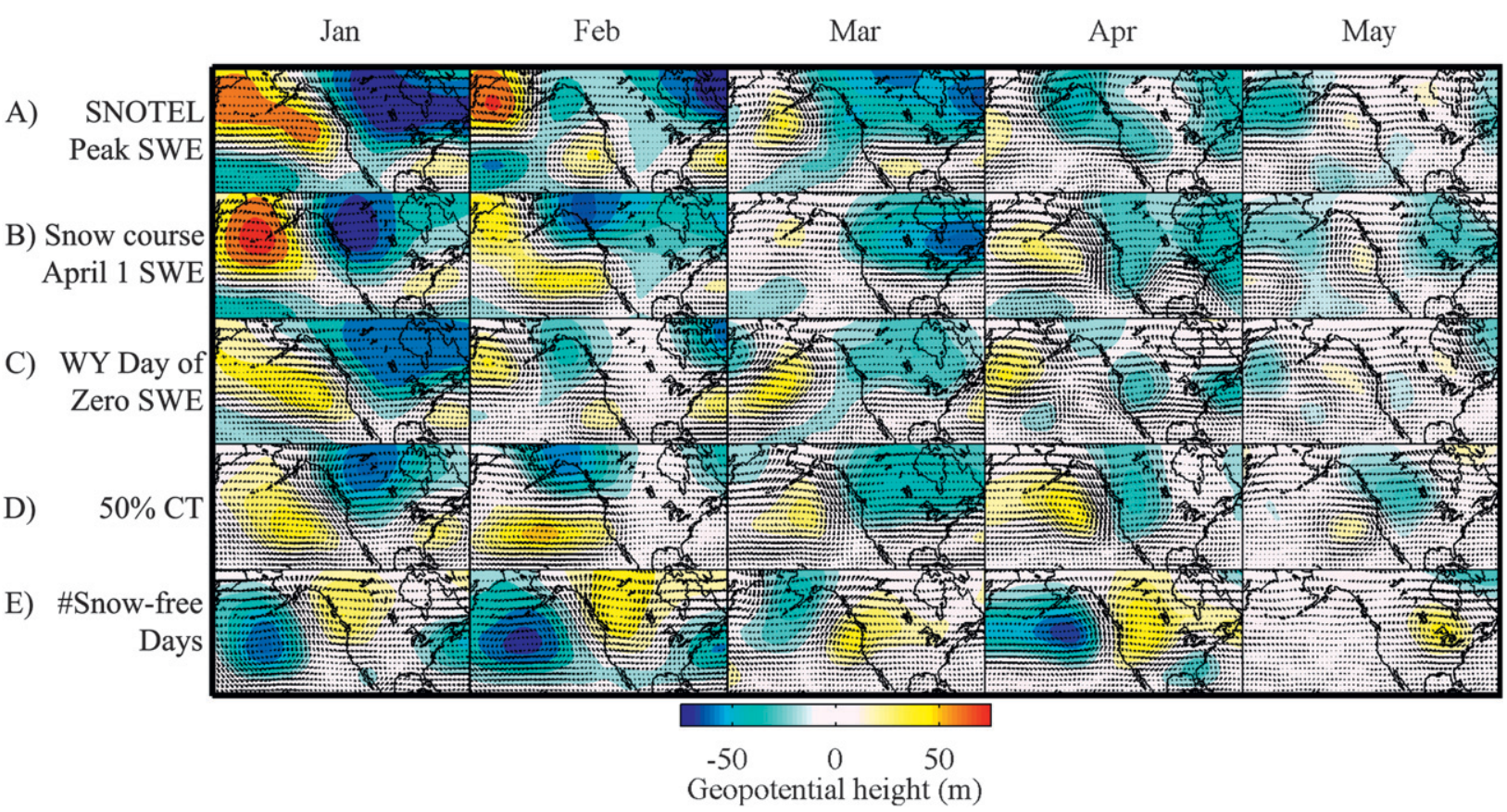

FIG. A2. Composite 500-mb monthly atmospheric pressure and wind anomaly maps for NRM hydroclimatic variables $\geq 1$ std dev from the long-term mean. Maps are arranged in the following order: (a) SNOTEL peak SWE, (b) snow course 1 Apr SWE, (c) day of zero SWE, (d) day of $50 \% \mathrm{CT}$, and (e) number of annual snow-free days.

over the Aleutian Islands and low pressure over the tropical Pacific and northwestern North America during the core winter months (JFM) (Figs. A2a,b). Inverse pressure and wind patterns are shown for years of anomalously low snowpack (Figs. A3a,b). The early (late) arrival of snowpack meltout date and streamflow $\mathrm{CT}$ is associated with high (low) pressure centered over western North America during the spring months (MAM)

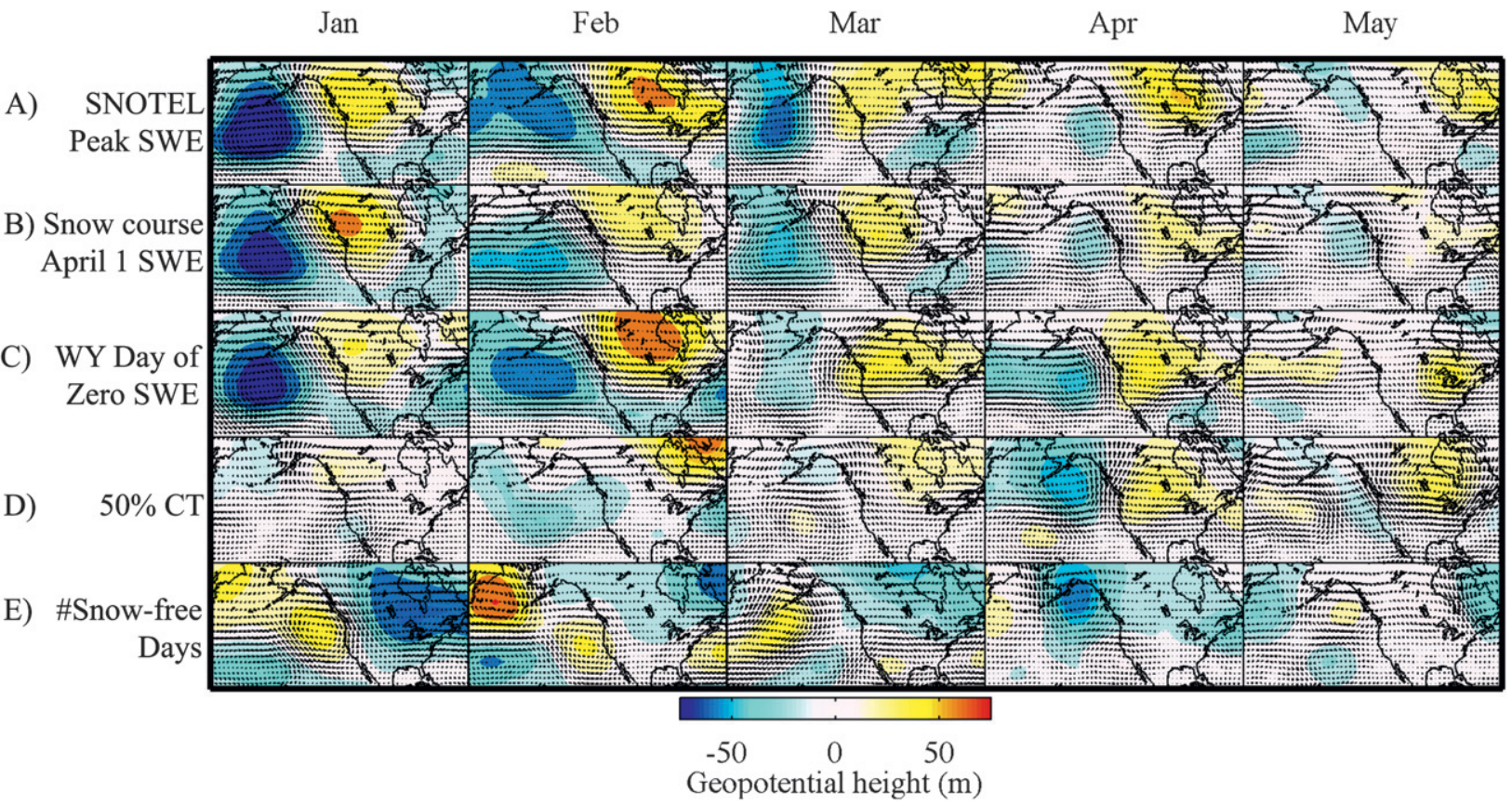

FIG. A3. As in Fig. A2, but for composite maps associated with NRM hydroclimatic variables $\leq 1 \mathrm{std}$ dev from the long-term mean. 
with the strongest atmospheric pressure and wind anomalies shown during the month of April (Figs. A1c,d and A2c,d). The same patterns hold true for the regional average number of snow-free days with Figs. A2e and A3e, showing that springs characterized by high (low) pressure result in higher (lower) temperatures and more (fewer) snow-free days.

\section{REFERENCES}

Adam, J. C., A. F. Hamlet, and D. P. Lettenmaier, 2009: Implications of global climate change for snowmelt hydrology in the 21st century. Hydrol. Processes, 23, 962-972.

Aguado, E., D. Cayan, L. Riddle, and M. Roos, 1992: Climatic fluctuations and the timing of West Coast streamflow. J. Climate, 5, 1468-1483.

An, S.-I., J.-S. Kug, A. Timmermann, I.-S. Kang, and O. Timm, 2007: The influence of ENSO on the generation of decadal variability in the North Pacific. J. Climate, 20, 667-680.

Ault, T. R., A. K. Macalady, G. T. Pederson, J. L. Betancourt, and M. D. Schwartz, 2011: Northern Hemisphere modes of variability and the timing of spring in western North America. $J$. Climate, in press.

Barnett, T. P., R. Malone, W. Pennell, D. Stammer, B. Semtner, and W. Washington, 2004: The effects of climate change on water resources in the west: Introduction and overview. Climatic Change, 62, 1-11.

, and Coauthors, 2008: Human-induced changes in the hydrology of the western United States. Science, 319, 1080 1083.

Bohr, G. S., and E. Aguado, 2001: Use of April 1 SWE measurements as estimates of peak seasonal snowpack and total coldseason precipitation. Water Resour. Res., 37, 51-60.

Cayan, D. R., 1996: Interannual climate variability and snowpack in the western United States. J. Climate, 9, 928-948.

— M. D. Dettinger, H. F. Diaz, and N. E. Graham, 1998: Decadal variability of precipitation over western North America. J. Climate, 11, 3148-3166.

— S. A. Kammerdiener, M. D. Dettinger, J. M. Caprio, and D. H. Peterson, 2001: Changes in the onset of spring in the western United States. Bull. Amer. Meteor. Soc., 82, 399-415.

Clow, D. W., 2010: Changes in the timing of snowmelt and streamflow in Colorado: A response to recent warming. J. Climate, 23, 2293-2306.

Das, T., and Coauthors, 2009: Structure and detectability of trends in hydrological measures over the western United States. J. Hydrometeor., 10, 871-892.

Dettinger, M. D., and D. R. Cayan, 1995: Large-scale atmospheric forcing of recent trends toward early snowmelt runoff in California. J. Climate, 8, 606-623.

,-- , and G. J. McCabe, 1994: Decadal trends in runoff over the western U.S. and links to persistent North Pacific sea surface temperature and atmospheric circulation patterns. Proc. 18th Annual NOAA Climate Diagnostics Workshop, Boulder, CO, NOAA, 240-243.

,-- M. K. Meyer, and A. E. Jeton, 2004: Simulated hydrologic responses to climate variations and change in the Merced, Carson, and American river basins, Sierra Nevada, California, 1900-2099. Climatic Change, 62, 283-317.

Diaz, H. F., and J. K. Eischeid, 2007: Disappearing "Alpine tundra" Koppen climatic type in the western United States. Geophys. Res. Lett., 34, L18707, doi:10.1029/2007GL031253.
Dong, B., R. T. Sutton, and A. A. Scaife, 2006: Multidecadal modulation of El Niño-Southern Oscillation (ENSO) variance by Atlantic Ocean sea surface temperatures. Geophys. Res. Lett., 33, L08705, doi:10.1029/2006GL025766.

Draper, N. R., and H. Smith, 1998: Applied Regression Analysis. 3rd ed. Wiley, $736 \mathrm{pp}$.

Enfield, D. B., 2001: Evolution and historical perspective of the 1997/1998 El Niño-Southern Oscillation event. Bull. Mar. Sci., 69, 7-25.

- A. M. Mestas-Nunez, and P. J. Trimble, 2001: The Atlantic multidecadal oscillation and its relation to rainfall and river flows in the continental US. Geophys. Res. Lett., 28, 2077 2080.

Hamlet, A. F., D. Fluharty, D. P. Lettenmaier, N. J. Mantua, E. L. Miles, P. W. Mote, and L. Whitely-Binder, 2001: Effects of climate change on water resources in the Pacific Northwest: Impacts and policy implications. S. Preparatory White Paper for Climate and Water Policy Meeting, Climate Impacts Group, $16 \mathrm{pp}$.

, P. W. Mote, M. P. Clark, and D. P. Lettenmaier, 2007: Twentieth-century trends in runoff, evapotranspiration, and soil moisture in the western United States. J. Climate, 20, $1468-1486$.

Hidalgo, H. G., and Coauthors, 2009: Detection and attribution of streamflow timing changes to climate change in the western United States. J. Climate, 22, 3838-3855.

Kalnay, E., and Coauthors, 1996: The NCEP/NCAR 40-Year Reanalysis Project. Bull. Amer. Meteor. Soc., 77, 437-471.

Karl, T. R., H. F. Diaz, and G. Kukla, 1988: Urbanization: Its detection and effect in the United States climate record. J. Climate, 1, 1099-1123.

Karoly, D. J., and Q. Wu, 2005: Detection of regional surface temperature trends. J. Climate, 18, 4337-4343.

Knowles, N., and D. R. Cayan, 2004: Elevational dependence of projected hydrologic changes in the San Francisco estuary and watershed. Climatic Change, 62, 319-336.

— M. D. Dettinger, and D. R. Cayan, 2006: Trends in snowfall versus rainfall in the western United States. J. Climate, 19, 4545-4559.

Luce, C. H., and Z. A. Holden, 2009: Declining annual streamflow distributions in the Pacific Northwest United States, 1948-2006. Geophys. Res. Lett., 36, L16401, doi:10.1029/2009GL039407.

Mantua, N. J., S. R. Hare, Y. Zhang, J. M. Wallace, and R. C. Francis, 1997: A Pacific interdecadal climate oscillation with impacts on salmon production. Bull. Amer. Meteor. Soc., 78, 1069-1079.

McCabe, G. J., and M. P. Clark, 2005: Trends and variability in snowmelt runoff in the western United States. J. Hydrometeor., 6, 476-482.

- M. A. Palecki, and J. L. Betancourt, 2004: Pacific and Atlantic Ocean influences on multidecadal drought frequency in the United States. Proc. Natl. Acad. Sci. USA, 101, 4136-4141.

_ J. L. Betancourt, S. T. Gray, M. A. Palecki, and H. G. Hidalgo, 2008: Associations of multidecadal sea surface temperature variability with US drought. Quat. Int., 188, 31-40.

Mekis, E., and W. D. Hogg, 1999: Rehabilitation and analysis of Canadian daily precipitation time series. Atmos.-Ocean, 37, 53-85.

Menne, M. J., and C. N. Williams Jr., 2005: Detection of undocumented changepoints using multiple test statistics and composite reference series. J. Climate, 18, 4271-4286.

,-- , and R. S. Vose, 2009: The United States historical climatology network monthly temperature data-Version 2 . Bull. Amer. Meteor. Soc., 90, 993-1007. 
Moore, J. N., J. T. Harper, and M. C. Greenwood, 2007: Significance of trends toward earlier snowmelt runoff, Columbia and Missouri Basin headwaters, western United States. Geophys. Res. Lett., 34, L16402, doi:10.1029/2007GL031022.

Mote, P. W., 2003: Trends in snow water equivalent in the Pacific Northwest and their climatic causes. Geophys. Res. Lett., 30 1601, doi:10.1029/2003GL017258.

_ 2006: Climate-driven variability and trends in mountain snowpack in western North America. J. Climate, 19, 62096220 .

_ A. F. Hamlet, M. P. Clark, and D. P. Lettenmaier, 2005: Declining mountain snowpack in western north America. Bull. Amer. Meteor. Soc., 86, 39-49.

Newman, M., G. P. Compo, and M. A. Alexander, 2003: ENSOforced variability of the Pacific decadal oscillation. J. Climate, 16, 3853-3857.

Pederson, G. T., D. B. Fagre, S. T. Gray, and L. J. Graumlich, 2004: Decadal-scale climate drivers for glacial dynamics in Glacier National Park, Montana, USA. Geophys. Res. Lett., 31, L12203, doi:10.1029/2004GL019770.

_ L. L. Graumlich, D. Fagre, T. Kipfer, and C. Muhlfeld, 2010: A century of climate and ecosystem change in Western Montana: What do temperature trends portend? Climatic Change, 98, 133-154.

Pierce, D. W., and Coauthors, 2008: Attribution of declining Western U.S. snowpack to human effects. J. Climate, 21, 6425-6444.

Prato, T., and D. Fagre, Eds., 2007: Sustaining Rocky Mountain Landscapes: Science, Policy, and Management for the Crown of the Continent Ecosystem. 1st ed. Resources for the Future Press, $321 \mathrm{pp}$.

Quadrelli, R., and J. M. Wallace, 2004: A simplified linear framework for interpreting patterns of Northern Hemisphere wintertime climate variability. J. Climate, 17, 3728-3744.

Rajagopalan, B., K. Nowak, J. Prairie, M. Hoerling, B. Harding, J. Barsugli, A. Ray, and B. Udall, 2009: Water supply risk on the Colorado River: Can management mitigate? Water Resour. Res., 45, W08201, doi:10.1029/2008WR007652.

Rauscher, S. A., J. S. Pal, N. S. Diffenbaugh, and M. M. Benedetti, 2008: Future changes in snowmelt-driven runoff timing over the western US. Geophys. Res. Lett., 35, L16703, doi:10.1029/ 2008 GL034424.

Regonda, S. K., B. Rajagopalan, M. Clark, and J. Pitlick, 2005: Seasonal cycle shifts in hydroclimatology over the western United States. J. Climate, 18, 372-384.

Rocky Mountain Climate Working Group, 2010: Rocky Mountain Climate protocol: Climate monitoring in the Greater Yellowstone and Rocky Mountain Inventory and Montioring
Networks, version 1.0. National Park Service Natural Resource Rep. NPS/IMRO/NRR-2010/222, 65 pp.

Rood, S. B., G. M. Samuelson, J. K. Weber, and K. A. Wywrot, 2005: Twentieth-century decline in streamflows from the hydrographic apex of North America. J. Hydrol., 306, 215-233.

Schaefer, G. L., and R. F. Paetzold, 2010: SNOTEL (Snopack Telemetry) and SCAN (Soil Climate Analyses Network): Automated weather stations for applications in agriculture and water resources management: Current use and future perspectives. [Available online at http://www.wcc.nrcs.usda. gov/publications/factsheets.html.]

Schwartz, M. D., and B. E. Reiter, 2000: Changes in North American spring. Int. J. Climatol., 20, 929-932.

Seaber, P. R., F. P. Kapinos, and G. L. Knapp, 1987: Hydrologic unit maps. U.S. Geological Survey water-supply paper 2294, 63 pp.

Selkowitz, D. J., D. B. Fagre, and B. A. Reardon, 2002: Interannual variations in snowpack in the crown of the continent ecosystem. Hydrol. Processes, 16, 3651-3665.

Serreze, M., M. Clark, R. Armstrong, D. Mcginnis, and R. Pulwarty, 1999: Characteristics of the western United States Snowpack from Snowpack Telemetry (SNOTEL) data. Water Resour. Res., 35, 2145-2160.

Solomon, S., D. Qin, M. Manning, M. Marquis, K. Averyt, M. M. B. Tignor, H. L. Miller Jr., and Z. Chen, Eds., 2007: Climate Change 2007: The Physical Science Basis. Cambridge University Press, 996 pp.

Stewart, I. T., D. R. Cayan, and M. D. Dettinger, 2005: Changes toward earlier streamflow timing across western North America. J. Climate, 18, 1136-1155.

Thompson, D. W. J., and J. M. Wallace, 2000: Annular modes in the extratropical circulation. Part I: Month-to-month variability. J. Climate, 13, 1000-1016.

_ _ J. J. Kennedy, J. M. Wallace, and P. D. Jones, 2008: A large discontinuity in the mid-twentieth century in observed globalmean surface temperature. Nature, 453, 646-649.

Vincent, L. A., B. R. Zhang, B. R. Bonsal, and W. D. Hogg, 2002: Homogenization of daily temperatures over Canada. J. Climate, 15, 1322-1344.

Watson, E., G. Pederson, B. Luckman, and D. Fagre, 2008: Glacier mass balance in the northern U.S. and Canadian Rockies: Paleo-perspectives and 20th century change. Darkening Peaks, L. B. B. Orlove and E. Wiegandt, Eds., University of California Press, 139-151.

Zhang, R., and T. L. Delworth, 2007: Impact of the Atlantic multidecadal oscillation on North Pacific climate variability. Geophys. Res. Lett., 34, L23708, doi:10.1029/2007GL031601. 